\title{
НОВЫЙ ВЗГЛЯД НА ГИДРОГЕОЛОГИЧЕСКИЕ УСЛОВИЯ ГОРОДА ФЕДЕРАЛЬНОГО ЗНАЧЕНИЯ СЕВАСТОПОЛЬ
}

\author{
Новиков Дмитрий Анатольевич ${ }^{12,}$ \\ NovikovDA@ipgg.sbras.ru \\ Черных Анатолий Витальевич', \\ ChernykhAV@ipgg.sbras.ru \\ Дульцев Федор Федорович', \\ DultsevFF@ipgg.sbras.ru
1 Институт нефтегазовой геологии и геофизики им. А.А. Трофимука Сибирского отделения Российской академии наук, Россия, 630090, г. Новосибирск, пр. Академика Коптюга, 3.
${ }^{2}$ Новосибирский национальный исследовательский государственный университет, Россия, 630090, г. Новосибирск, ул. Пирогова, 1. довых) по территории города федерального значения Севастополь и составлении в соответствии с существующими методиче скими рекомендациями схемы гидрогеологической стратификации и гидрогеологической карты нового поколения впервые за последние 50 лет. Изучаемая территория имеет богатую историю с античного времени и как следствие круглогодично является излюбленным местом в туристических маршрутах по Крымскому полуострову. Увеличивающийся поток туристов и удовлетворение текущих и перспективных потребностей Севастопольской городской агломерации в качественной питьевой воде является одной из первостепенных задач обеспечения социальной стабильности, охраны здоровья и увеличения продолжительности жизни населения (436 тыс. человек на 01.01.2018). В настоящее время на территории города для целей централизованного хозяйственно-питьевого водоснабжения используются 9 водозаборов (Орловский, Любимовский, Родниковский и другие). Большинство из них эксплуатируют водоносный комплекс миоценовых отложений. Если проанализировать ситуацию с подземным водоснабжением города Севастополя в целом, можно констатировать что утвержденные эксплуатационные запасы на действующих водозаборах используются в лучшем случае на 30-40 \%, за исключением Инкерманского, где этот показатель достигает 90-93 \%. Но вопрос с подземным водоснабжением и развитием действующих водозаборов не является простым. Ошибки при эксплуатации Орловского водозабора в 1980-е гг. уже привели к катастрофическим последствиям по изменению химического состава подземных вод эксплуатируемого водоносного горизонта. В этой связи вопрос о подземном водоснабжении необходимо начинать с создания современной гидрогеологической модели, что в первую очередь подразумевает актуализацию схемы гидрогеологической стратификации и гидрогеологической карты города Севастополя.

Цель работы: на основе детального анализа архивных, опубликованных и полевых исследований выявить особенности гидрогеологического строения города федерального значения Севастополь и составить в соответствии с существующими методическими рекомендациями схему гидрогеологической стратификации и гидрогеологическую карту нового поколения.

Методы. Использованы методические приемы И.К. Зайцева, Б.Н. Архангельского, Е.Л. Баскова, М.С. Альтовского, А.С. Рябченкова, Н.В. Роговской, М.Р. Никитина, Б.Е. Антыпко и других, а также последние методические рекомендации МПР России и ВСЕГЕИ по составлению гидрогеологических карт и схем гидрогеологической стратификации, фондовые и опубликованные данные.

Результаты. Проведено обобщение гидрогеологических данных по территории города федерального значения Севастополь (включая результаты полевых работ авторского коллектива 2017-2018 гг.), актуализирована гидрогеологическая карта и составлена схема стратификации нового поколения. Приводятся сведения об основных водоносных комплексах и горизонтах в районе, а также краткая характеристика химического состава подземных вод. На исследуемой территории выделены два водоносных этажа (мезозойский и кайнозойский), объединяющие в себе 7 водоносных комплексов: 1) комплекс плиоценовых и четвертичных отложений $\left.-8\left(N_{2}-a Q\right) ; 2\right)$ миоценовый $\left.-8\left(N_{1}\right) ; 3\right)$ палеоценово-эоценовый $\left.-8\left(P_{1}-P_{2}\right) ; 4\right)$ верхнемеловой $\left.-8\left(K_{2}\right) ; 5\right)$ нижне-

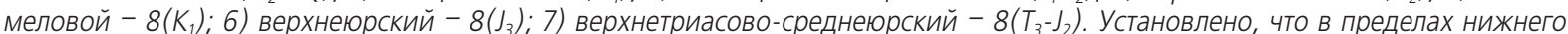
(мезозойского) водоносного этажа распространены трещинно-поровые, трещинно-карстовые, пластово-трещинные и напорные пластово-трещинные воды с величиной общей минерализации преимущественно до 1,5 г/дм³ , тогда как в верхнем (кайнозойском) водоносном этаже их минерализация варьирует от 0,4-0,5 до 10,3 г/дм (до 35 г/дм³ в прибрежных районах). По химическому составу (по классификации С.А. Щукарева) воды весьма разнообразны и представлены 37 химическими типами от пресных гидрокарбонатных кальциевых до соленых хлоридных натриевых. Доминируют подземные воды гидрокарбонатного, гидрокарбонатно-хлоридного и хлоридного кальциевого и кальциево-натриевого типов с величиной общей минерализации, варьирующей в интервале от 0,16 до 2,63 г/дм³.

\section{Ключевые слова:}

Подземные воды, гидрогеологическая карта, гидрогеологическая стратификация, город федерального значения Севастополь, Крым.

\section{Введение}

В последние годы все больше исследований в мире проводится по оценке ресурсной базы, проблемам качества и загрязнения питьевых подзем- ных вод в условиях изменяющегося климата. По самым оптимистичным прогнозам, среднегодовая температура на Земле вырастет к началу следующего столетия как минимум на два градуса 
Цельсия вне зависимости от действий человека, что заставит климат планеты необратимым образом поменяться. Волны жары, засухи и другие экстремальные погодные явления, а также рост уровня моря будут гораздо более опасными при повышении температур на два градуса и выше [1]. 0.В. Парубец рассмотрены тенденции изменения температуры воздуха и количества атмосферных осадков на протяжении 80-летнего интервала времени в Крыму. Установлено, что температура воздуха и количество атмосферных осадков растут [2].

Работы учёных разных стран посвящены вопросам: оценки экологического состояния подземных вод в пределах территорий с разной степенью антропогенной нагрузкой; водоснабжения городских агломераций; прогноза водопотребления в будущем и другим. Особенно широко они обсуждаются в странах Африки, Азии и Латинской Америки, где вопросы водоснабжения населения стоят наиболее остро. Так, следует отметить последние работы по мониторингу качества подземных вод городов Алжира, Камеруна, Бангладеш, Индии, Нигера, Израиля, Словении, США и других стран. Различным аспектам проблемы хозяйственно-питьевого водоснабжения населения городов, в том числе загрязнения, посвящены многочисленные работы по различным регионам мира [3-32].

Территория города федерального значения Ceвастополь имеет богатую историю с античного времени и как следствие круглогодично является излюбленным местом в туристических маршрутах по Крымскому полуострову. Увеличивающийся поток туристов и удовлетворение текущих и перспективных потребностей Севастопольской городской агломерации в качественной питьевой воде является одной из первостепенных задач обеспечения социальной стабильности, охраны здоровья и увеличения продолжительности жизни населения (436 тыс. человек на 01.01.2018). Научного обобщения гидрогеологических материалов по изучаемой территории не проводилось около 50 лет. С 1970-х гг. в запущены в эксплуатацию несколько водозаборов (Орловский, Родниковский и другие), накоплен большой объем фактического материала по результатам геологоразведочных работ на подземные воды. Авторским коллективом с 2017 г. проводятся экспедиционные работы. В настоящей статье представлены результаты исследований по гидрогеологии города Севастополя, выполненные в соответствии с последними методическими рекомендациями МПР России и ВСЕГЕИ по составлению гидрогеологических карт и схем гидрогеологической стратификации [33-36].

Гидрогеологическая стратификация и районирование лежит в основе любых гидрогеологических исследований. Разработке теоретических основ гидрогеологической стратификации посвящены многочисленные работы Н.И. Толстихина, А.М. Овчинникова, Г.Н. Каменского, М.К. Кучина, Ф.П. Саваренского, М.С. Гуревича, К. Кейльгака, Н.К. Игнатовича, П.Ф. Швецова, И.К. Зайце- ва, Н.А. Маринова, А.С. Рябченкова, Е.В. Пиннекера, А.А. Карцева, В.Н. Корценштейна, Б.Ф. Маврицкого, А.А. Розина, П.П. Климентова, У. Рихтера, В.А. Кирюхина, О.В. Равдоникас, Н.В. Роговской, А. Турнера, К.П. Караванова, Л.А. Островского, С.Л. Шварцева, В.Б. Торговановой, Н.М. Кругликова, С.Г. Бейрома, Ю.К. Смоленцева, В.В. Нелюбина, Б.П. Ставицкого, В.М. Матусевича, П.А. Удодова, А.Д. Назарова, Ю.П. Гаттенбергера, Н.Ф. Чистяковой и многих других.

\section{Объект, материалы и методы исследований}

В соответствии с принятым гидрогеологическим районированием Крыма, составленным Е.А. Ришес [37, 38], и картой подземных вод: L-(36), (37), составленной во ВСЕГЕИ в 1983 г. под редакцией И.Н. Павловец [39], территория г. Севастополя расположена в пределах двух гидрогеологических структур: Альминского артезианского бассейна Равнинно-Крымского артезианского бассейна и гидрогеологической складчатой области мегаантиклинория Горного Крыма. В границах Равнинно-Крымского артезианского бассейна выделено Альминское месторождение подземных вод, в пределах гидрогеологической складчатой области мегаантиклинория Горного Крыма - ЗападноКрымское месторождение подземных вод. В этой связи необходимо было обобщить большой комплекс геологических, гидрогеологических и гидрогеохимических данных (опубликованных и фондовых), в первую очередь результаты картирования разного времени, выполненного специалистами ведущих научных и производственных организаций СССР, Украины и России [40-50], а также результаты полевых работ 2017-2018 гг. В гидрогеологической стратификации при расчленении разрезов выделяются следующие основные гидрогеологические подразделения: водоносные и водоупорные горизонты, водоносные комплексы, ярусы и этажи [34]. Наиболее мелкой таксономической единицей является водоносный горизонт. Водоносный горизонт - относительно выдержанная по площади и в разрезе насыщенная гравитационной водой одно- или разновозрастная толща горных пород, представляющая собой в гидродинамическом отношении единое целое [51]. При выделении водоносных горизонтов необходимо учитывать, что их мощность не должна превышать мощность стратиграфических ярусов, реже отделов.

Составление гидрогеологической карты и схемы гидрогеологической стратификации нового поколения велось в несколько этапов: 1) обобщение имеющихся гидрогеологических материалов по гидродинамическим, гидрогеохимическим и геотермическим особенностям водоносных горизонтов; 2) обобщение результатов полевых работ на территории Севастопольской городской агломерации, проведенных в 2017-2018 гг. (маршрутные наблюдения, результаты гидрогеохимического опробования скважин и родников); 3) составление схемы гидрогеологической стратификации разре- 
за и 4) актуализация гидрогеологической карты. Основными критериями выделения водоносных, водоупорных и относительно водоупорных толщ в разрезе являются литологический и минералогический составы пород и их физические свойства. В качестве непосредственных показателей установления изолирующих свойств водоупорных толщ следует опираться на показатели гранулометрического состава, пористости, проницаемости. Информационный банк данных включает записи по более чем 300 скважинам на подземные воды и 37 родникам.

\section{Результаты и их обсуждение}

В гидрогеологической стратификации юго-западной части Крымского полуострова, включая территорию города Севастополь, приведенной в Гидрогеологии СССР под ред. А.В. Сидоренко [37], было выделено 8 подразделений (сверху вниз): водоносный комплекс средне-верхнеплиоценовых отложений, водоносный комплекс сарматских, мэотических и понтических отложений, водоносный горизонт среднемиоценовых отложений, водоносный комплекс палеоценовых и эоценовых отложений, водоносный комплекс верхнемеловых отложений, водоносный комплекс нижнемеловых отложений, водоносная зона трещиноватости верхнеюрских отложений и водоупорные отложения таврической серии и средней юры. Согласно стратификации 2006 г., выполненной специалистами Министерства экологии и природных ресурсов Украины [52], в гидрогеологическом разрезе было выделено 6 водоносных горизонтов и 4 комплекса (сверху вниз): водоносный комплекс плиоценовых континентальных и эоплейстоценовых аллювиальных отложений, водоносный горизонт средневерхнесарматских отложений, водоносный горизонт среднемиоценовых отложений, водоносный горизонт эоценовых отложений, водоносный горизонт палеоценовых отложений, локальный водоносный комплекс трещиноватости верхнемеловых отложений, водоносный комплекс нижнемеловых отложений, водоносный горизонт верхнеюрских отложений, локальный водоносный горизонт зон трещиноватости пород средней юры и локальный водоносный горизонт экзогенной трещиноватости пород таврической серии. Имеющиеся различия сведены на рис. 1.

Согласно действующим нормативным документам, ни одна из представленных ранее схем не соответствует современным требованиям по составлению схем гидрогеологической стратификации, не соблюден таксономический ряд выделяемых подразделений [34]. В предлагаемой актуализированной схеме гидрогеологической стратификации региона выделены водоупорные горизонты на основе фациально-литологического состава пород и более дробно представлен верхний гидрогеологический этаж, а именно гидрогеологические подразделения плиоцен-миоценовых отложений. Все уточнения и детализирование гидрогеологическо- го разреза проводилось на основе фациально-литологического состава горных пород, определяющего наличие в геологическом разрезе водоносных и водоупорных гидрогеологических тел и характер их взаимоотношения, а также характер гидравлической связи между смежными подразделениями, содержащими подземные воды.

На территории исследования в границах фанерозоя выделяются два водоносных этажа: верхний - кайнозойский, который является зоной активного водообмена, и нижний, мезозойский - затрудненного водообмена. Представленное описание основных гидрогеологических подразделений проведено в соответствии и имеющимся информационным банком данных и опубликованными и фондовыми материалами [37, 38, 53-65].

Анализ опубликованных данных и имеющегося фактического материала позволил выделить семь водоносных комплексов (сверху вниз): 1) комплекс плиоценовых и четвертичных отложений, 2) миоценовый, 3) палеоценово-эоценовый, 4) верхнемеловой, 5) нижнемеловой, 6) верхнеюрский и 7) верхнетриасово-среднеюрский.

Перечисленные комплексы были разделены на водоносные и водоупорные горизонты (рис. 2), описание областей их распространения приведено ниже в соответствии с составленной гидрогеологической картой (рис. 3) [66].

Водоносный комплекс плиоценовых и четвертичных отложений $\left(8\left(\mathrm{~N}_{2}\right.\right.$-aQ) $)$ распространен на северо-западе и севере исследуемого региона, а также в долинах рек Черная, Бельбек и Кача. Изучен множеством скважин: № 5752, 1037, 1515, 1195, 1195a, 501, 601, 1895, 19-1, 19-3, 38м, 1789, 52н, $87 \mathrm{~m}, 1067,1053$. Его мощность составляет 100-120 м. Комплекс включает в себя водоносный горизонт четвертичных отложений $(\mathrm{aQ})$, водоносный горизонт средне-верхнеплиоценовых отложений $\left(2\left(\mathrm{~N}_{2}{ }^{2-3}\right)\right)$ и нижнеплиоценовый водоупорный горизонт $\left(4\left(\mathrm{~N}_{2}{ }^{1}\right)\right)$. Водоносный горизонт четвертичных отложений представлен отложениями гравия, галечника, песка с прослоями суглинков и глин. На территории Севастополя воды этого горизонта эксплуатируют Бельбекский (расположен в 4 км от с. Верхнесадовое) и Инкерманский (расположен в Инкерманской долине, между п. Сахарная Головка и с. Штурмовое) водозаборы. Горизонт безнапорный, глубина залегания уровней подземных вод изменяется от 12 до 24 м. На незначительных участках горизонт переходит в напорный, когда он перекрыт сверху толщей суглинков или глин мощностью до 2,5-3,5 м. Удельные дебиты скважин варьируют в широком интервале от 0,1 до 36 л/с. Водопроводимость составляет 34-4680 м²/сут, при доминировании значений от 500 до $1000 \mathrm{~m}^{2} /$ сут. Область питания совпадает с областью его распространения. В долине реки Кача горизонт четвертичных отложений образует единый напорный водоносный горизонт с известняками сарматского возраста. Воды по химическому составу относятся к гидрокарбонатному кальциевому типу с величи- 


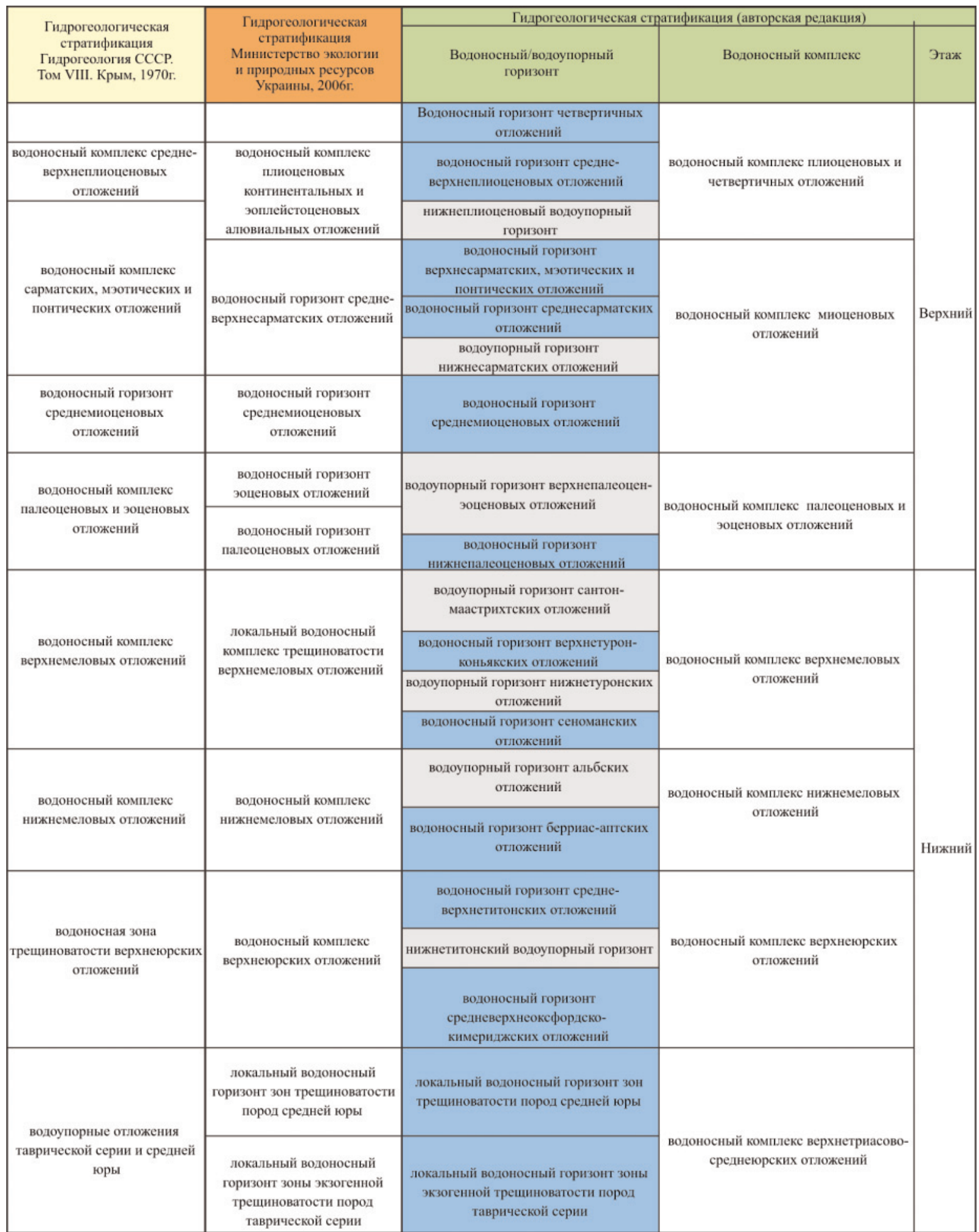

Рис.1. Сравнительная схема гидрогеологической стратификаиии города федерального значения Севастополь

Fig. 1. Comparative scheme of hydrogeological stratification scheme of the city of federal significance Sevastopol

ной общей минерализации $0,5-1,0$ г/дм². Водоносный горизонт средне-верхнеплиоценовых отложений представлен линзами песков и галечников в толще песчаных глин верхнетаврской (андреевской) подсвиты. На исследуемой территории централизованно не эксплуатируется. Имеются от- дельные скважины в частных домовладениях. Горизонт напорно-безнапорный. Безнапорный на участках, где он первый от поверхности земли, и напорный на территории развития глин, отделяющих его от горизонта четвертичных отложений. Глубина залегания уровней подземных вод изме- 
няется от 7,1 до 60 м. Удельные дебиты скважин варьируют в интервале от 0,001 до 1,5 л/с. Значения водопроводимости колеблются от 0,77 до $148 \mathrm{~m}^{2} /$ сут. Минерализация подземных вод колеблется от 0,4 до 10,3 г/дм ${ }^{3}$, состав сульфатный, гидрокарбонатно-сульфатный кальциевый, вдоль морского побережья хлоридный и сульфатно-хлоридный натриевый. Нижнеплиоценовый водоупорный горизонт представлен глинами нижнетаврской (учкуивской) подсвиты.

Водоносный комплекс миоценовых отложений $\left(8\left(\mathrm{~N}_{1}\right)\right)$ мощностью до 400 м распространен на востоке и юго-востоке Севастопольской городской агломерации (рис. 3) и представлен водоносными горизонтами верхнесарматских, мэотических и понтических отложений $\left(2\left(\mathrm{~N}_{1} \mathrm{~s}_{3}-\mathrm{N}_{1} \mathrm{~m}-\mathrm{N}_{1} \mathrm{p}\right)\right)$, среднесарматских отложений $\left(2\left(\mathrm{~N}_{1} \mathrm{~s}_{2}\right)\right)$, среднемиоценовых отложений $\left(2\left(\mathrm{~N}_{1}^{2}\right)\right)$, а также водоупорным горизонтом нижнесарматских отложений $\left(4\left(\mathrm{~N}_{1} \mathrm{~s}_{1}\right)\right)$ (рис. 1). Комплекс вскрывают скважины № 1037, 1515 , 1195, 1195a, 1501, 601, 1895, 5752, 19-1, 19-3. Водоносный горизонт верхнесарматских, мэотических и понтических отложений сложен кавернозными известняками, гравелитами, песчаниками и песками херсонской свиты. На исследуемой территории воды этого горизонта эксплуатирует Орловский водозабор (расположен в с. Орловка). Горизонт напорный, глубина залегания уровней подземных вод изменяется от 55 до 120 м. Мощность водоносного горизонта составляет 52-73 м. Величина напора варьирует от 19 до 37,8 м. Удельные дебиты скважин достигают 64,0-91,1 л/с, а водопроводимость составляет 1000-6000 м²/сут. Как отмечалось выше, в долине реки Кача он имеет гидравлическую взаимосвязь с горизонтом аллювиальных четвертичных отложений. Минерализация горизонта не превышает 1 г/дм ${ }^{3}$, но по приближению к морю растет до 32 г/дм³. Воды гидрокарбонатно-сульфатные, гидрокарбонатные, гидрокарбонатно-хлоридные кальциево-натриевые, а в засоленных участках и на побережье хлоридные натриевые. Водоносный горизонт среднесарматских отложений сложен известняками с прослоями песков, песчаников, глин и конгломератов бесарабской свиты. Водоносный горизонт повсеместно напорный, напоры подземных вод изменяется от 46 до 235 м, возрастая с запада на восток. Удельные дебиты скважин изменяются от 0,14 до 23,2 л/с, а водопроводимость составляет от 27 до $2960 \mathrm{~m}^{2} /$ сут (преобладающие значения 50-250 $\mathrm{m}^{2} /$ сут). Наиболее высокая водообильность отмечена на западе описываемого участка. Питание за счет инфильтрации атмосферных осадков горизонт получает в предгорных районах - в местах выхода среднесарматских отложений на дневную поверхность. Воды гидрокарбонатные, гидрокарбонатно-сульфатные, хлоридные кальциевые и кальциево-натриевые с минерализацией на большей части распространения горизонта от 1,0 до 1,5 г/дм ${ }^{3}$ и до хлоридных натриевых с минерализацией $10,0-46,8$ г/дм ${ }^{3}$ в прибрежных районах
[67]. Водоупорный горизонт нижнесарматских отложений представлен глинами с редким прослоем мергелей и алевролитов красноперекопской свиты мощностью до 90 м. Водоносный горизонт среднемиоценовых отложений сложен переслаиванием песчаников, карбонатных песков, глин, известняков и гравелитов брикивского, спанидеолитового, сартаганского, веселеняского слоев и мекензиевской толщи. На территории Севастопольской городской агломерации воды этого горизонта эксплуатируют четыре водозабора: Водограй (Гагаринский район, Фиолентовское шоссе), Делегардовский (г. Севастополь, ул. Делегатская, д. 2), Любимовский (в р-не с. Любимовка) и Царьхлебский (г. Севастополь, ул. Токарева, д. 2В). Водоносный горизонт имеет преимущественно напорный режим. Он безнапорный в областях выхода его отложений на дневную поверхность в пределах Гераклейского полуострова, где работают водозаборы Водограй и Делегардовский, где уровни подземных вод изменяются от 40 до 72 м, и в предгорных районах. Величина напора увеличивается по мере погружения водовмещающих пород и достигает более 250 м. Глубина пьезометрических уровней варьирует от нескольких метров выше дневной поверхности до 108 м ниже. Водообильность пород изменяется как по площади, так и в разрезе. Водопроводимость составляет 54,9-2291 м²/сут (преобладающие значения 100-200 м²/сут). Удельные дебиты скважин охватывают диапазон от 0,26 до 20,8 л/с. Движение подземных вод происходит от области питания в предгорных районах на запад, север и северо-восток. Источником питания служат атмосферные осадки и фильтрация из рек - на небольших участках в предгорных районах. Разгрузка подземных вод осуществляется в акватории Черного моря. Воды горизонта гидрокарбонатные кальциевые, хлоридно-гидрокарбонатные кальциевые и натриево-кальциевые, хлоридные натриевые с минерализацией преимущественно до 1 г/дм ${ }^{3}$. От предгорий в западном направлении происходит закономерный рост величины общей минерализации подземных вод от 0,3 до 4,7-10,0 г/дм в прибрежных районах и смена химического типа с гидрокарбонатного кальциевого на хлоридный натриевый.

Водоносный комплекс палеоценовых и эоценовых отложений $\left(8\left(\mathrm{P}_{1}-\mathrm{P}_{2}\right)\right)$ развит в Севастопольской бухте и на северо-западе исследуемой территории. Изучен скважиной № 38м. Его мощность может достигать 400 м. Комплекс представлен водоупорным горизонтом верхнепалеоцен-эоценовых отложений $\left(4\left(\mathrm{P}_{1}^{2}-\mathrm{P}_{2}\right)\right)$ и водоносным горизонтом нижнепалеоценовых отложений $\left(2\left(\mathrm{P}_{1}^{1}\right)\right)$. Водоупорный горизонт верхнепалеоцен-эоценовых отложений сложен мергелями и глинами качинской, новопавловской, кумской и альминской свит. Водоносный горизонт нижнепалеоценовых отложений приурочен к трещиноватым закарстованным известнякам и песчаникам белокаменской свиты. Водоносный горизонт напорно-безнапорный, уровни подземных вод в 
скважинах изменяются от 3,3 до 83 м. Мощность нижнепалеоценовых известняков может достигать 70 м. Степень обводненности горизонта крайне неравномерная, наибольшая (удельные дебиты 0,5-2,0 л/с) - в районах, примыкающих к области питания в предгорных районах. Севернее, в районе города Бахчисарай, удельные дебиты ряда скважин достигают 35 л/с при понижении до 20 м. Питание осуществляется также за счет инфильтрации атмосферных осадков в предгорных районах. Минерализация вод составляет 0,4-0,5 г/дм ${ }^{3}$, состав гидрокарбонатный кальциевый.

Водоносный комплекс верхнемеловых отложений $\left(8\left(\mathrm{~K}_{2}\right)\right)$ распространен в восточной части изучаемого района и включает в себя водоупорный горизонт сантон-маастрихтских отложений $\left(4\left(\mathrm{~K}_{2} \mathrm{st}-\mathrm{K}_{2} \mathrm{~m}\right)\right)$, водоносный горизонт верхнетурон-коньякских отложений $\left(2\left(\mathrm{~K}_{2} \mathrm{t}_{2}-\mathrm{K}_{2} \mathrm{k}\right)\right)$, водоупорный горизонт нижнетуронских отложений $\left(4\left(\mathrm{~K}_{2} \mathrm{t}_{1}\right)\right)$ и водоносный горизонт сеноманских отложений $\left(2\left(\mathrm{~K}_{2} \mathrm{~s}\right)\right)$. Комплекс вскрыт скважиной № 38м. Мощность комплекса до 950 м. Водоупорный горизонт сантон-маастрихтских отложений представлен мергелями, песковатыми мергелями с алевритистыми конкрециями и карбонатными глинами кудринской, бешковской и старосельской свит. Водоносные горизонты сеноманских и верхнетурон-коньякских отложений представлены трещиноватыми известняками и мергелями с пропластаками песчаников белогорской и прохладненской свит. Водоупорный горизонт нижнетуронских отложений сложен мергелями мендерской свиты. Водоносный комплекс приурочен к зонам экзогенной трещиноватости пород и к зонам тектонических нарушений. Водоносные горизонты комплекса имеют напорно-безнапорный режим фильтрации. Дебиты источников составляют 0,1-0,5 л/с, скважин - 0,1-0,6 л/с. Водопроводимость известняков комплекса невысока и изменяется в интервале от 0,09 до $25,9 \mathrm{~m}^{2} /$ сут. Питание водоносного комплекса осуществляется атмосферными осадками, а в случае его перекрытия - за счет межпластовых перетоков из вышезалегающих водоносных горизонтов. Доминируют воды гидрокарбонатного кальциевого состава с величиной общей минерализации 0,4-0,5 г/дм³ ${ }^{3}$ В погруженных частях Альминского бассейна в северо-западной части изучаемого региона минерализация подземных вод растет до 10-40 г/дм ${ }^{3}$, а химический тип изменяется на хлоридный натриевый.

Водоносный комплекс нижнемеловых отложений $\left(8\left(\mathrm{~K}_{1}\right)\right)$ распространен в южной части территории исследования и включает в себя водоносный горизонт берриас-аптских отложений $\left(2\left(\mathrm{~K}_{1} \mathrm{~b}-\mathrm{K}_{1} \mathrm{a}\right)\right)$ и водоупорный горизонт альбских отложений (4( $\left.\left.\mathrm{K}_{1} \mathrm{al}\right)\right)$. Комплекс вскрывают скважины № 105н, $100 \mathrm{H}, 87$ м. Мощность комплекса может достигать 1400 м (рис. 4). Водоносный горизонт берриас-аптских отложений включает в себя породы свиты Бечку, кучкинской, новобобровской, широковской и балаклавской толщ. Водоносными порода- ми этих свит являются трещиноватые и слаботрещиноватые песчаники и известняки, галечники с конгломератами бериасс-готеривского возраста, готерив-баремские песчанники и конгломераты. Водоносный горизонт имеет безнапорный режим в областях выхода его отложений на дневную поверхность в пределах Байдарской долины и центральной части региона исследования и переходит в напорный режим при погружении. Водообильность пород изменяется как по площади, так и в разрезе. Удельные дебиты источников составляют 0,1-0,2 л/с. Мощность обводненных зон составляет до 75 м. Статические уровни подземных вод изменяются от 70 до 114 м. Питание осуществляется также за счет атмосферных осадков и межпластовых перетоков из ниже залегающих верхнеюрских карстующихся известняков. Естественная разгрузка подземных вод осуществляется в акватории Черного моря и посредством восходящих и нисходящих источников в материковой части. Воды гидрокарбонатные кальциево-натриевые, минерализация не превышает 1 г/дм ${ }^{3}$. Водоупорный горизонт альбских отложений включает в себя глины, аргиллиты и алевролиты чоргунской и канаринской толщ.

Водоносный комплекс верхнеюрских отложений $\left(8\left(\mathrm{~J}_{3}\right)\right)$ присутствует на юге исследуемой территории и включает в себя водоносный горизонт средне-верхнетитонских отложений $\left(2\left(\mathrm{~J}_{3} \mathrm{tt}_{2-3}\right)\right)$, нижнетитонский водоупорный горизонт $\left(4\left(\mathrm{~J}_{3} \mathrm{t} \mathrm{t}_{1}\right)\right)$ и водоносный горизонт средневерхнеоксфордско-кимериджских отложений $\left(2\left(\mathrm{~J}_{3} \mathrm{O}_{2-3}-\mathrm{J}_{3} \mathrm{~km}\right)\right)$ (рис. 3,4$)$. Изучен скважинами № $105 \mathrm{H}, 52 \mathrm{H}, 100 \mathrm{H}, 87 \mathrm{~m}$. Его мощность достигает 2000 м. Водоносный горизонт средне-верхнетитонских отложений представлен двумя свитами - калафатларской и байдарской. Калафатларская свита сложена полимиктовыми конгломератами с глыбами известняков яйлинской свиты. Цемент глинисто-карбонатный, тип цементации - базально-поровый. Байдарская свита представлена разными типами известняков: брекчеподобными, пелитоморфными, органогенными и коралловыми.

Нижнетитонский водоупорный горизонт состоит из отложений деймень-деринской свиты, которая, в свою очередь, разделяется на две подсвиты. Нижняя сложена флишеподобным переслаиванием серых алевролитовых глин и коричнево-серых обломочных известняков. Верхняя посвита представлена серыми алевритистыми глинами с конкрециями сидеритов и прослойками обломочных известняков. Водоносный горизонт средневерхнеоксфордско-кимериджских отложений включает в себя яйлинскую и сохуроченскую свиты. Яйлинская свита разделяется на две подсвиты. Нижняя представлена коричнево-серыми известняками с прослоями алевролитовых известняков, линзами песчаников и алевролитов. Верхняя подсвита состоит из коричнево-серых известняков, с пачками песчанистых и глинистых известняков и мергелей. Сухореченская свита в целом предста- 


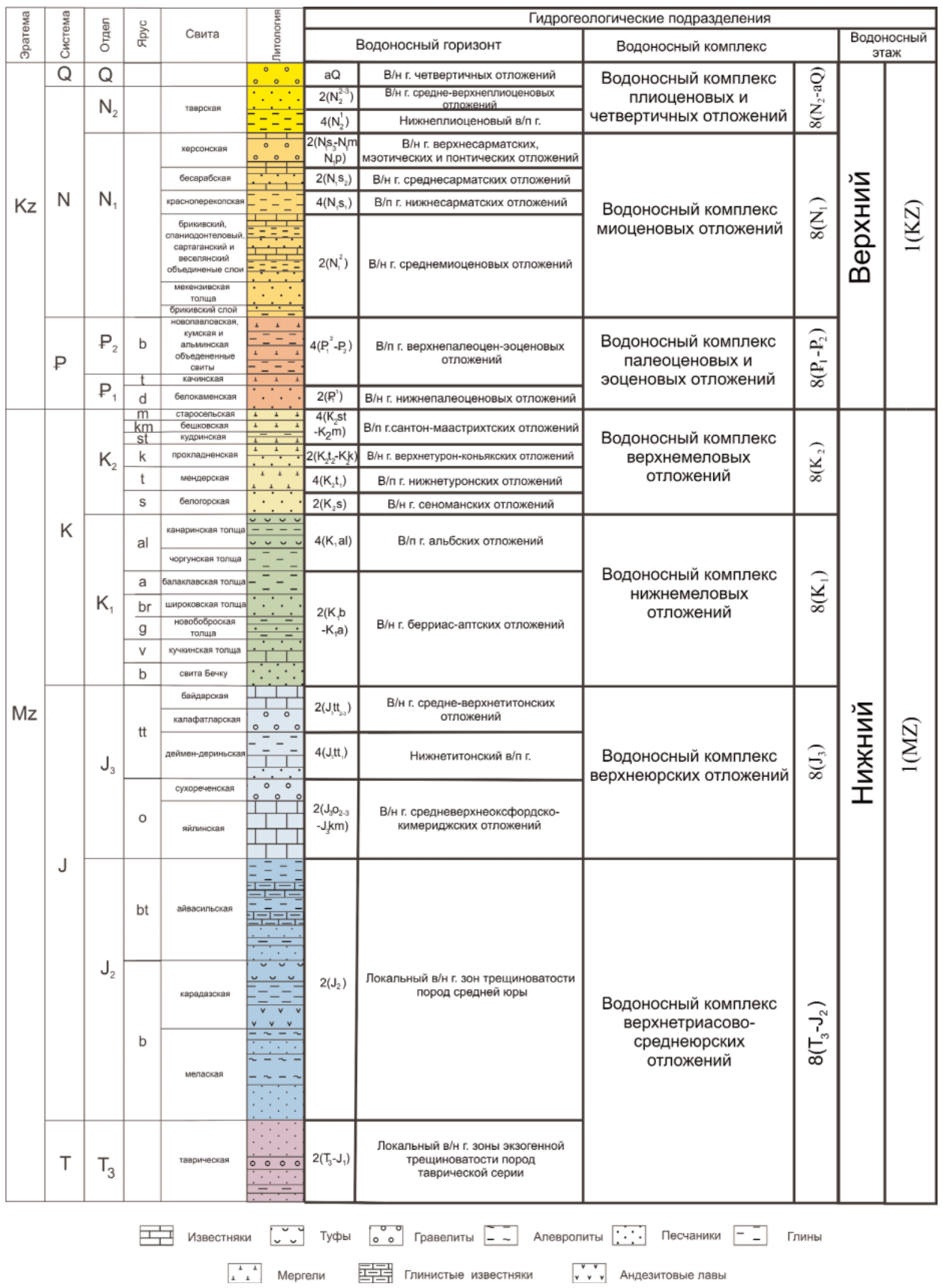

Pис. 2. Схема гидрогеологической стратификации города федерального значения Севастополь. В/н г.- водоносный горизонт, в/ $\mathrm{n}$ г. - водоупорный горизонт

Fig. 2. Hydrogeological stratification scheme of the city of federal significance Sevastopol. B/H 2. - water bearing formation; $8 / n$ 2. - unpermeable layer 
влена конгломератами с линзами грубозернистых песчаников и органогенных известняков.

Водоносный комплекс трещинно-карстовых вод имеет напорный режим в областях перекрытия его нижнемеловыми отложениями в Байдарской долине (рис. 3,4$)$ и центральных частях Севастопольской городской агломерации. В Байдарской долине, где работает Родниковский водозабор, величина напора меняется от 38,2 до 776,5 м, на остальной территории - от 11 до 192 м. Безнапорный режим для комплекса характерен в областях выхода его отложений на дневную поверхность в пределах Ай-Петринской яйлы Главной гряды Крымских гор. Водообильность верхнеюрских известняков весьма неравномерна. Дебиты скважин, полученные при откачках, изменяются от 0,2 до 50 л/с при понижениях уровня от 1,75 до 113 м. Удельные дебиты изменяются от тысячных долей до 11,0 л/с. Величина водопроводимости достигает значений $685,7-845,0 \mathrm{~m}^{2} /$ сут.

Особое значение имеет родник Скельский (основной) со среднегодовым многолетним расходом 1840 л/с. Установлено, что родник Скельский и скважины Родниковского водозабора представляют собой единую гидравлическую систему. Родник является примером естественно разгрузки указанной системы и его выход приурочен к наиболее обводненной ее части. Как показали результаты экспедиционных и аналитических работ 2018 г., эти водопункты имеют практически одинаковый химический состав, а величина их общей минерализации не превышает 0,3 г/дм ${ }^{3}$. Источником питания комплекса служат атмосферные осадки, а разгрузка подземных вод осуществляется в виде многочисленных источников, по трещинам в подрусловых отложениях р. Черной и с помощью субмаринных источников в акватории Черного моря поблизости с мысом Айя и в Балаклавской бухте. Воды данного комплекса пластово-трещинные, пресные, гидрокарбонатные кальциевые, кальциевомагниевые (Родниковский участок Западно-Крымского месторождения с величиной общей минерализации до 0,3 г/дм³ $)$, реже гидрокарбонатно-хлоридные, хлоридно-сульфатные с минерализацией до 1 г/дм ${ }^{3}[68-72]$.

Водоносный комплекс верхнетриасово-среднеюрских отложений $\left(8\left(\mathrm{~T}_{3}-\mathrm{J}_{2}\right)\right)$ присутствует на юге Севастопольской агломерации и включает в себя два локальных водоносных горизонта: $30 н$ трещиноватости пород средней юры $\left(2\left(\mathrm{~J}_{2}\right)\right)$ и зоны экзогенной трещиноватости пород таврической серии $\left(2\left(\mathrm{~T}_{3}-\mathrm{J}_{1}\right)\right)$. На территории исследования комплекс имеет выходы на поверхность вдоль южного побережья рядом с м. Сарич и м. Айя. Мощность комплекса может достигать 2200 м. Локальный водоносный горизонт зоны трещиноватости пород средней юры $\left(2\left(\mathrm{~J}_{2}\right)\right)$ представлен породами айвасильской, карадазской и мелаской свит. Карадазская свита разделена на три подсвиты. Нижняя сложена андезибазальтовыми и андезитовыми ла- вами с прослойками туфов, средняя подсвита представлена аргиллитами и алевролитами с конкрециями сидеритов, верхняя состоит из литокристаллических андезитовых туфов с прослойками туфитов и песчаников. Мелаская свита также разделяется на три подсвиты. Нижняя сложена серыми песчаниками, карбонатными алевролитами и тонкоплиточными аргиллитами. Средняя подсвита состоит из алевролитов с линзами и конкрециями сидеритов с переслаивающимися пачками алевролитов и песчаников. Верхнюю слагают переслаивающиеся песчанико-алевролитовые и аргиллитовые слои с пачками туфов. Айвасильская свита подразделяется на три подсвиты. Нижняя подсвита состоит из полимиктовых песчаников с линзами гравелитов и пачками флишеподобно переслаивающихся песчаников, алевролитов и глин с конкрециями сидеритов. Средняя представлена флишеподобным переслаиванием песчаников, глин с конкрециями сидеритов и глинистыми известняками. Верхняя подсвита - загипсованными глинами с окремненными пачками песчано-аргиллитового флиша с конкрециями сидеритов. Водоносный горизонт имеет ограниченное распространение и крайне слабо изучен ввиду повышенной минерализации до 3,0 г/дм ${ }^{3}$ подземных вод. Удельные дебиты скважин могут достигать 0,2 л/с. Воды этого горизонта напорные, трещинно-карстовые и пластово-трещинные. По составу хлоридно-гидрокарбонатные натриевые с минерализацией 2,6-3,0 г/дм ${ }^{3}$ В пределах локального водоносного горизонта зоны экзогенной трещиноватости пород таврической серии $\left(2\left(\mathrm{~T}_{3}-\mathrm{J}_{1}\right)\right)$ выделяются крымская и эскординская свиты. Основной литолого-петрографический состав пород крымской свиты - песчаники, алевролиты, аргиллиты и сидериты. Эскординская свита разделяется на две подсвиты. Нижняя подсвита по составу схожа с породами крымской свиты, но с включениями аргиллита с линзами серых и рыжих известняков. Верхняя подсвита сложена светло-серыми и желтыми кварцитоподобными и аркозовыми песчаниками, полимиктовыми конгломератами с жилками аргиллитов и алевролитов и линзами известняков. Водоносный горизонт также имеет ограниченное распространение и слабо изучен с гидрогеологической точки зрения. Воды этого горизонта трещинно-поровые, напорные с удельными дебитами скважин до 1,15 л/с. Севернее изучаемого региона в Бахчисарайском районе водоносный горизонт разгружается в виде известного источника радоновых вод "Аджи-Су» с среднегодичным удельным дебитом 0,15 л/с. Воды источника хлоридные натриево-кальциевые с минерализацией 4,06-5,52 г/дм ${ }^{3}$, составе водорастворенных газов (ВРГ) присутствуют: азот, метан, сероводород, гелий, а также радон. Содержания «традиционных» микрокомпонентов составляют $($ мг/дм $): \mathrm{I}-0,4-1,8 ; \mathrm{B}-2,6-5,1 ; \mathrm{Br}-1,6-5,3 ; \mathrm{F}-$ $0,3-0,7$. 


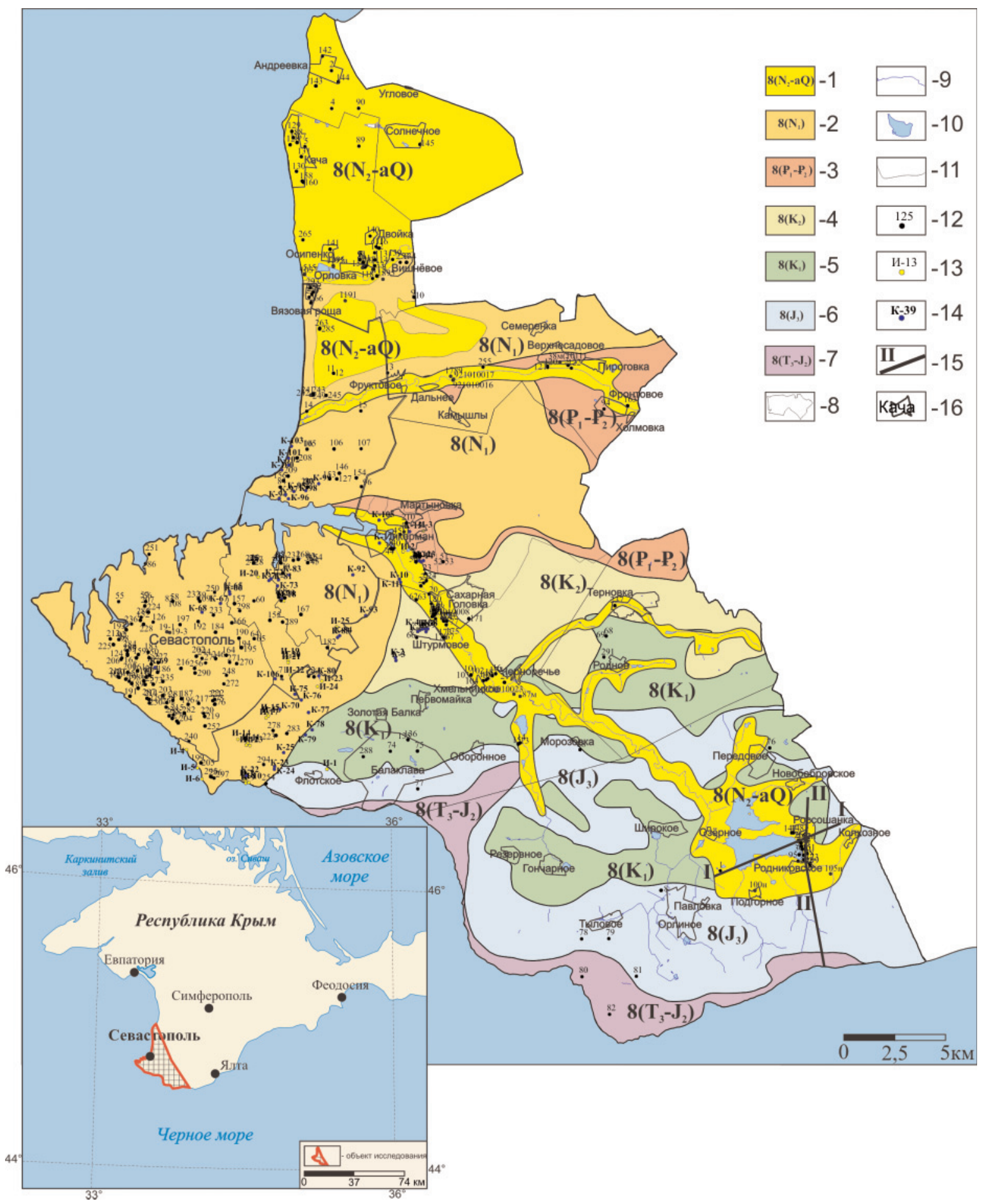

Рис. 3. Гидрогеологическая карта территории Севастопольской городской агломерации. Водоносный колплекс: 1 - плиоценовых и четвертичных отложений, 2 - миоценовых отложений, 3 - палеоцен-эоценовых отложений, 4 - верхнемеловых отложений, 5 нижнемеловых отложений, 6 - верхнеюрских отложений, 7 - верхнетриасово-среднеюрских отложений; 8 - адлинистративные границы районов; 9 - речная сеть; 10 - озера, водохранилища; 11 - границы гидрогеологических колплексов; 12 - скважины; 13 - источники; 14 - колодиы; 15 -линии гидрогеологических разрезов; 16 - населенные пункты

Fig. 3. Hydrogeological map of Sevastopol city agglomeration territory. Aquiferous complex: 1 - Pliocene and Quaternary sediments, 2 - Miocene sediments, 3 - Paleocene-Eocene sediments, 4 - Upper Cretaceous sediments, 5 - Lower Cretaceous sediments, 6 - Upper Jurassic sediments, 7 - Upper Triassic-Middle Jurassic sediments; 8 - administrative boundaries of the districts; 9 - river network; 10 - lakes, reservoirs; 11 - boundaries of hydrogeological complexes; 12 - boreholes; 13 - sources; 14 - wells; 15 - lines of hydrogeological sections; 16 - localities 

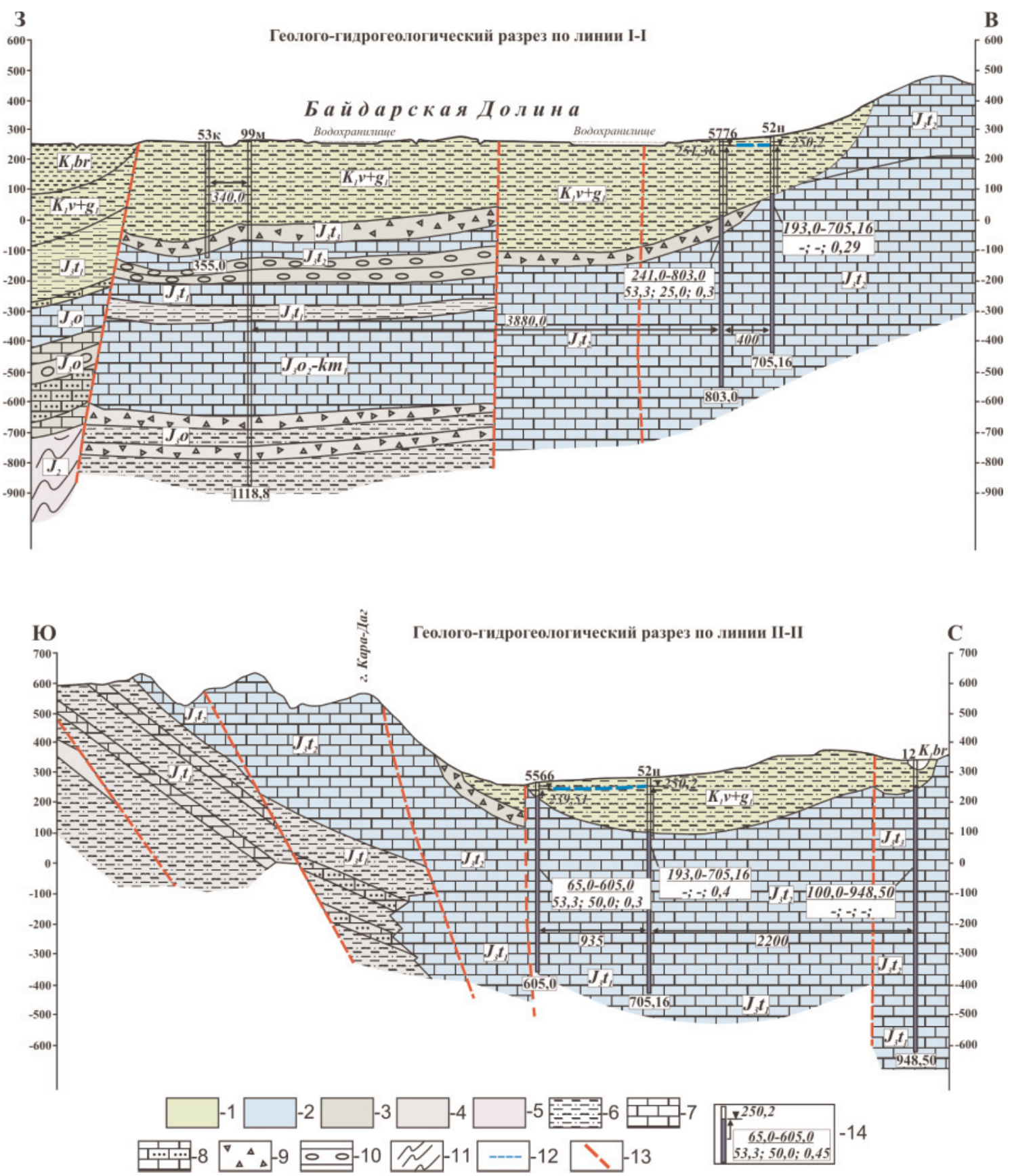

Puс. 4. Гидрогеологические разрезы по линиям I-I, II-II. 1 - водоупорные и слабопроницаелые (практически безводные) отложения нижнего мела; 2 - водоносный горизонт в карбонатной толще верхней юры. Массивные и грубослоистые известняки различной степени трещиноватости и закарстованности; 3 - водоносный горизонт в карбонатной толще верхней юры. Переслаивание слоистых и тонкослоистых известняков, песчаников, аргиллитов; глыбовые известняки, конгломераты, брекчии, трещиноватые, слабозакарстованные; 4 - водоупорные и слабопронииаемые (практически безводные) отложения верхней юры; 5 - водоупорные и слабопроницаемые (практически безводные) отложения средней юры; 6 - аргиллиты, алевролиты, глины; 7 - известняки; 8 - песчаники; 9 - брекчии; 10 - конгломераты; 11 - флиш; 12 - предполагаемое положение уровня подземных вод в верхнеюрских отложениях; 13 - предполагаемые разрывные нарушения; 14 - абсолютная отметка уровня воды, м; в квадрате - чи-

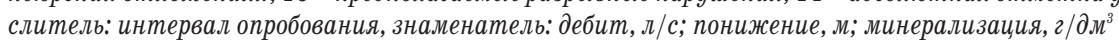

Fig. 4. Hydrogeological sections along the lines I-I,II-II.1 - unpermeable and weakly permeable (practically waterless) sediments of the Lower Cretaceous; 2 - aquifer in the carbonate layer of the Upper Jurassic. Massive and coarse-shaped limestones of varying degrees of fracturing and cartilage; 3 - aquifer in the carbonate layer of the Upper Jurassic. Overlapping of layered and thin-layer limestones, sandstones, argillites; slab limestones, conglomerates, breccia, fractured, weakly arched; 4 - unpermeable and weakly permeable (practically waterless) deposits of the Upper Jurassic; 5 - unpermeable and weakly permeable (practically waterless) deposits of the Middle Jurassic; 6 - argillites, siltstones, clay; 7 - limestone; 8 -sandstone; 9 - breccia; 10 - conglomerates; 11 - flush; 12 - the proposed position of the groundwater level in Upper Jurassic deposits; 13 - the proposed faults; 14 - absolute mark of water level, $m$; in the square the numerator: interval of testing, denominator: debit, $l / s e c$; lowering, $m ;$ mineralization, $g / \mathrm{dm}^{3}$ 


\section{Заключение}

Резюмируя вышесказанное, следует отметить, что в соответствии с действующими нормативными документами, ни одна из представленных ранее схем не соответствовала современным требованиям по составлению схем гидрогеологической стратификации и не соблюден таксономический ряд выделяемых подразделений [34]. В предлагаемой нами актуализированной схеме гидрогеологической стратификации региона выделены водоупорные горизонты на основе фациально-литологического состава пород и более дробно представлен верхний гидрогеологический этаж, а именно гидрогеологические подразделения плиоцен-миоценовых отложений. Все уточнения и детализирование гидрогеологического разреза проводилось на основе фациально-литологического состава горных пород, определяющего наличие в геологическом разрезе водоносных и водоупорных гидрогеологических тел и характер их взаимоотношения, а также характера гидравлической связи между смежными подразделениями, содержащими подземные воды. В соответствии с ней на территории Севастопольской городской агломерации выделяется два водоносного этажа: мезозойский и кайнозойский. В пределах нижнего (мезозойского) водоносного этажа развиты 4 водоносных комплекса: верхне-триасовых, верхнеюрских, нижнемеловых и верхнемеловых отложений. Подземные воды в их границах трещинно-поровые, трещинно-карстовые, пластово-трещинные и напорные пластово-трещинные с величиной общей минерализации преимущественно до 1,5 г/дм и разнообразным химическим составом от гидрокарбонатных кальциевых до хлоридных натриевых. Верхний (кайнозойский) водоносный этаж представлен водоносными комплексами палеоценово-эоценовых, миоценовых, плиоценовых и четвертичных отложений. Минерализация подземных вод этих комплексов колеблется в широком диапазоне и составляет от $0,4-0,5$ до 10,3 г/дм ${ }^{3}$ (до 35 г/дм в прибрежных районах), по составу также пестрые от

\section{СПИСОК ЛИТЕРАТУРЫ}

1. Less than $2^{\circ} \mathrm{C}$ warming by 2100 unlikely / A.E. Raftery, A. Zimmer, D.M.V. Frierson, R. Startz, P. Liu // Nature Climate Change. $-2017 .-$ V. 7 - P. 637-641.

2. Парубец 0.В. Изменение климата в Крыму // Ученые записки Таврического национального университета им. В.И. Вернадского. Серия: География. - 2009. - Т. 22 (61). - № 2. C. $88-96$.

3. Groundwater beneath the urban area of Khan Younis City, southern Gaza Strip (Palestine): assessment for multi-domestic purposes / M.S. Abu Jabal, I. Abustan, M.R. Rozaimy, H. El Najar // Arabian Journal of Geosciences. - 2017. - V. 10. -P. 257-272.

4. Aloni A., Brenner A. Use of Cotton as a Carbon Source for Denitrification in Biofilters for Groundwater Remediation // Water. - 2017. - V. 9. - P. 714-725.

5. Arora A.S. Urban stormwater - greywater management system for sustainable urban water management at sub-watershed level // E3S Web of Conferences 22. - 2017. - $7 \mathrm{p}$. пресных гидрокарбонатных кальциевых до соленых хлоридных натриевых.

В настоящее время на территории города для целей централизованного хозяйственно-питьевого водоснабжения используются 9 водозаборов (Opловский, Любимовский, Родниковский и другие). Большинство из них эксплуатируют водоносный комплекс миоценовых отложений. Если проанализировать ситуацию с подземным водоснабжением города Севастополя в целом, можно констатировать что утвержденные эксплуатационные запасы на действующих водозаборах используются в лучшем случае на 30-40 \%, за исключением Инкерманского, где этот показатель достигает 90-93\% . Но вопрос с подземным водоснабжением и развитием действующих водозаборов не является простым. Ошибки при эксплуатации Орловского водозабора в 1980-е гг. уже привели к катастрофическим последствиям по изменению химического состава подземных вод эксплуатируемого водоносного горизонта. Характер существующих гидрогеохимических аномалий указывает на подток морских вод за счет сформированной депрессионной воронки при интенсивном водоотборе. Сокращение отбора подземных вод на водозаборе с 1988 г. в среднем на 24 тыс. м $^{3}$ /сутки благоприятно сказывается на гидродинамическом режиме водоносного горизонта в сарматских отложениях. В настоящее время водоотбор на водозаборе достигает 7,76-8,91 тыс. $\mathbf{м}^{3}$ /сут. После ограничения водоотбора фиксируется подъем уровня по всем наблюдательным скважинам [73]. Необходимо в дальнейшем проводить перераспределение нагрузки на отдельные скважины водозабора и дифференциацию водоотбора с целью улучшения гидродинамического и гидрохимического режима эксплуатируемого водоносного горизонта, но этот вопрос требует детальных исследований.

Исследование проводилось при финансовой поддержке Российского фонда фундаментальных исследований и города Севастополь в рамках научного проекта № 18-45-920032p_a.

6. Asadi P., Ataie-Ashtiani B., Beheshti A. Vulnerability assessment of urban groundwater resources to nitrate: the case study of Mashhad, Iran // Environmental Earth Sciences. - 2017. V. 76. - P. 41-56.

7. Mass balance of emerging contaminants in the water cycle of a highly urbanized and industrialized area of Italy / S. Castiglioni, E. Davoli, F. Riva, M. Palmiotto, P. Camporini, A. Manenti, E. Zuccato // Water Research. - 2018. - V. 131. - P. 287-298.

8. Arsenic in groundwater of the Kolkata Municipal Corporation (KMC), India: Critical review and modes of mitigation / D. Chakraborti, B. Das, M.M. Rahman, B. Nayak, A. Pal, M.K. Sengupta, S. Ahamed, Md.A. Hossain, U.K. Chowdhury, B. Kumar Biswas, K.C. Saha, R.N. Dutta // Chemosphere. - 2017. - V. 180. - P. 437-447.

9. Hydrochemical characteristics and the impact of anthropogenic activity on groundwater quality in suburban area of Urmia city, Iran / M. Chitsazan, N. Aghazadeh, Y. Mirzaee, Y. Golestan // Environment, Development and Sustainability. - 2017. - V. 21. № 1. - P. 1-21. 
10. Spatial analysis and health risk assessment of heavy metals concentration in drinking water resources / R.A. Fallahzadeh, M.T. Ghaneian, M. Miri, M.M. Dashti // Environmental Science and Pollution Research. - 2017. - V. 24. - P. 24790-24802.

11. Source apportionment of pollution in groundwater source area using factor analysis and positive matrix factorization methods X. Guo, R. Zuo, D. Shan, Y. Cao, J. Wang, Y. Teng, Q. Fu, B. Zheng // Human and Ecological Risk Assessment: an International Journal. - 2017. - V. 23. - № 6. - P. 1417-1436.

12. Jangam C., Pujari P. Impact of on-site sanitation systems on groundwater sources in a coastal aquifer in Chennai, India // Environmental Science and Pollution Research. - 2017. - V. 26. № 3. - P. 1-10.

13. Combined hydrogeological and nitrate modelling to manage water resources of the Middle Soummam Aquifer, Northeast of Algeria / F. Kessasra, M. Mesbah, Z. Khemissa, N. Bouab, S. KhaledKhodja, H. Lamari // Arabian Journal of Geosciences. - 2017. V. $10 .-$ P. $368-388$.

14. Lasagna M., De Luca D.A. Evaluation of sources and fate of nitrates in the western Po plain groundwater (Italy) using nitrogen and boron isotopes // Environmental Science and Pollution Research. - 2017. - V. 26. - № 3. - P. 1-16.

15. Lins-de-Barros F.M. Integrated coastal vulnerability assessment: A methodology for coastal cities management integrating socioeconomic, physical and environmental dimensions - Case study of Regia o dos Lagos, Rio de Janeiro, Brazil / / Ocean \& Coastal Management. - 2017. - V. 149. - P. 1-11

16. Nitrate - nitrogen contamination in groundwater: Spatiotemporal variation and driving factors under cropland in Shandong Province, China / J. Liu, L.H. Jiang, C.J. Zhang, P. Li, T.K. Zhao // IOP Conf. Series: Earth and Environmental Science. - 2017. V. 82. -012059

17. Rapid decadal evolution in the groundwater arsenic content of Kolkata, India and its correlation with the practices of her dwellers / A. Malakar, S. Islam, Md.A. Ali, S. Ray // Environmental Monitoring and Assessment. - 2016. - V. 188. - P. 584-595.

18. Passive sampling as a tool for identifying micro-organic compounds in groundwater / N. Mali, S. Cerar, A. Koroša, P. Auersperger // Science of the Total Environment. - 2017. - V. 593-594. P. 722-734.

19. Occurrence of chemical contaminants in peri - urban agricultural irrigation waters and assessment of their phytotoxicity and crop productivity / A. Margenat, V. Matamoros, S. Díez, N. Cañameras, J. Comas, J.M. Bayona // Science of the Total Environment. - 2017. - V. 599-600. - P. 1140-1148.

20. Impact of wastewater on groundwater resources in Sana'a basin, Yemen / K.A. Merghem, A. Jilali, A.A. Alnedhary, H.E. Halouani, K. Dssouli // Arabian Journal of Geosciences. - 2016. V. 9. - № 268. - P. 1-14.

21. Impact of urbanization coupled with drought situations on groundwater quality in shallow (basalt) and deeper (granite) aquifers with special reference to fluoride in Nanded - Waghala $\mathrm{Mu}$ nicipal Corporation, Nanded District, Maharashtra (India) / M. Pandith, R.D. Kaplay, S.S. Potdar, H. Sangnor, A.D. Rao // Environmental Monitoring and Assessment. - 2017. - V. 189. P. 428-442.

22. Hydrogeochemical and isotopic signature of surface and groundwater in a highly industrialized sector of the Rio de la Plata coastal plain (Argentina) / L. Santucci, E. Carol, G. Borzi, M.G. García // Marine Pollution Bulletin. - 2017. - V. 120. P. 387-395.

23. Selvakumar S., Chandrasekar N., Kumar G. Hydrogeochemical characteristics and groundwater contamination in the rapid urban development areas of Coimbatore, India // Water Resources and Industry. - 2017. - V. 17. - P. 26-33.

24. Geochemical Characteristics and Evaluation of Minor and Trace Elements Pollution in Groundwater of Tuticorin City, Tamil Na- du, India using Geospatial Techniques / S. Selvam, S. Venkatramanan, P. Sivasubramanian, S.Y. Chung, C. Singaraja // Journal Geological Society of India. - 2017. - V. 90, -P. 62-68.

25. Spatial and seasonal variations of surface and groundwater quality in a fast-growing city: Lubango, Angola / M.M.V.G. Silva, E.M.C. Gomes, M. Isaías, J.M.M. Azevedo, B. Zeferino // Environmental Earth Sciences. - 2017. - № 76. - P. 790-807.

26. Evaluation of groundwater quality and health risks from contamination in the north edge of the Loess Plateau, Yulin City, Northwest China / H. Su, W. Kang, Y. Xu, J. Wang // Environmental Earth Sciences. - 2017. - V. 76. - P. 467-488.

27. Hydrogeological effects of dredging navigable canals through lagoon shallows. A case study in Venice / P. Teatini, G. Isotton, S. Nardean, M. Ferronato, A. Mazzia, C. Da Lio, L. Zaggia, D. Bellafiore, M. Zecchin, L. Baradello, F. Cellone, F. Corami, A. Gambaro, G. Libralato, E. Morabito, A.V. Ghirardini, R. Broglia, S. Zaghi, L. Tosi // Hydrology and Earth System Sciences. 2017. - V. 21. - P. 5627-5646.

28. Weaver J.W., Murray A.R., Kremer F.V. Estimation of the proximity of private domestic wells to underground storage tanks: Oklahoma pilot study // Science of the Total Environment. 2017. - V. 609. - P. 1589-1599.

29. Hydrochemical profiles in urban groundwater systems: New insights into contaminant sources and pathways in the subsurface from legacy and emerging contaminants / D. White, D.J. Lapworth, M.E. Stuart, P.J. Williams // Science of the Total Environment. - 2016. - V. 562. - P. 962-973.

30. Wilson D.C. Potential urban runoff impacts and contaminant distributions in shoreline and reservoir environments of Lake Havasu, southwestern United States / Science of the Total Environment. - 2018. - V. 621. - P. 95-107.

31. Wyman D.A., Koretsky C.M. Effects of road salt deicers on an urban groundwater - fed kettle lake // Applied Geochemistry. 2018. - V. 89. - P. 265-272.

32. Assessing Risks at a Former Chemical Facility, Nanjing City, China: An Early Test of the New Remediation Guidelines for Waste Sites in China / Y. Zhang, S. Ye, J. Wu, R.G. Stahl Jr. // Water. - 2017. - V. 9. - P. 657-672.

33. Методическое письмо по подготовке схем гидрогеологической стратификации. - М.: Министерство природных ресурсов Российской Федерации, 1999. - 17 с.

34. Методические рекомендации по составлению карт гидрогеологического районирования масштаба 1:2500000, схем гидрогеологической стратификации и классификаторов объектов гидрогеологического районирования и стратификации. - М.: МПР России, 2004. -29 с.

35. Методическое руководство по составлению и подготовке к изданию листов Государственной геологической карты Российской Федерации масштаба 1:200000 (второго издания). Версия 1.2. - СПб.: Картографическая фабрика ВСЕГЕИ, 2015. $163 \mathrm{c.}$

36. Методическое руководство по составлению и подготовке к изданию листов Государственной геологической карты Российской Федерации масштаба 1:200000 (второе издание). Версия 1.3. СПб.: Картографическая фабрика ВСЕГЕИ, 2017. - 173 с.

37. Гидрогеология CCCP. T. VIII. Крым / гл. ред. академик А.В. Сидоренко. - М.: Изд-во «Недра», 1970. - 364 с.

38. Гидрогеология СCCP. T. VIII. Крым / гл. ред. академик А.В. Сидоренко. - М.: Изд-во «Недра», 1971. - 55 с.

39. Карта подземных вод: L-(36), (37). Государственная геологическая карта СССР (Симферополь). Карта подземных вод, масштаб: 1:1000000 / под ред. И.Н. Павловец. - СПб.: ФГБУ «ВСЕГЕИ», 1983.

40. Геологическая карта: L-36-XXXIV, XXXV. Геологическая карта СССР. Серия Крымская, масштаб: 1:200000, серия: Крымская / под ред. М.В. Муратова. - Днепропетровск: МГРИ им. С. Орджоникидзе, трест Днепрогеология, 1965. - 1 с. 
41. Геологическая карта: L-37-XIX, XXV. Государственная геологическая карта СССР. Серия Крымская, масштаб: 1:200000, серия: Крымская / под ред. М.В. Муратова. - Днепропетровск: трест Днепрогеология, трест Крымнефтегазразведка, 1971. $1 \mathrm{c.}$

42. Геологическая карта: L-36-XXIX. Геологическая карта CCCP. Серия Крымская, масштаб: 1:200000, серия: Крымская / под ред. М.А. Калацюк. - Киев: ЦКЛ треста «Киевгеология», 1973. - 1 c.

43. Геологическая карта: Геологическая карта Горного Крыма, масштаб: 1:20000 / под ред. Н.Е. Деренюк. - М.: Н.Е.МинГео CCCP, $1984 .-1 \mathrm{c}$.

44. Геологическая карта: L-(36), (37). Государственная геологическая карта СССР (Симферополь), масштаб: 1:1000000 / под ред. Д.Ф. Володина, П.Н. Сторчак. - Киев: Центральная тематическая экспедиция Министерства геологии Украинской CCP, 1986. - 1 c.

45. Геологическая карта: Геологическая карта Горного и Предгорного Крыма, масштаб: 1:200000 / под ред. В.В. Юдина. - Симферополь: Научно-производственный центр Союзкарта, 2009. $-1 \mathrm{c}$.

46. Карта домеловых отложений: L-(36), (37). Государственная геологическая карта СССР (Симферополь). Карта домеловых образований, масштаб: 1:1000000 / под ред. П.Н. Сторчак. СПб: ФГБУ «ВСЕГЕИ», 1983. -1 с.

47. Карта дочетвертичных образований: L-(36), (37). Государственная геологическая карта СССР (Симферополь). Карта дочетвертичных образований, масштаб: 1:1000000 / под ред. П.Н. Сторчак. - СПб: ФГБУ «ВСЕГЕИ», 1983. - 1 с.

48. Карта полезных ископаемых: L-37-XIX, XXV. Карта полезных ископаемых СССР. Серия Крымская, масштаб: 1:200000, серия: Крымская / под ред. М.В. Муратова. - Днепропетровск: трест Днепрогеология, трест Крымнефтегазразведка, 1971. $1 \mathrm{c.}$

49. Карта полезных ископаемых: L-(36), (37). Государственная геологическая карта СССР (Симферополь). Карта полезных ископаемых, масштаб: 1:1000000 / под ред. П.Н. Сторчак. СПб: ФГБУ «ВСЕГЕИ», 1983. - 1 с.

50. Карта четвертичных отложений: L-(36), (37). Государственная геологическая карта СССР (Симферополь). Карта четвертичных отложений, масштаб: 1:1000000 / под ред. П.Н. Сторчак. - СПб: ФГБУ «ВСЕГЕИ», 1983. - 1 с.

51. Шварцев С.ЈI. Общая гидрогеология. - М.: Недра, 1996. $423 \mathrm{c.}$

52. Геологическая карта Украины: Крымская серия: L-36-XXVIII, L-36-XXXIV, масштаб: 1:200000 / под ред. С.В. Билецкого. Киев: ГГСФП «Южногеоцентр», 2006. - 1 с.

53. Геология и нефтегазоносность степного и предгорного Крыма / Г.Х. Дикенштейн, Н.В. Безносов, Л.М. Голубничая, В.А. Загоруйко, А.Е. Каменецкий, А.М. Моксякова, А.П. Ослоповский, О.В. Снегирева, В.Г. Хельквист, Е.К. Шуцкая. - М.: Государственное научно-техническое издательство нефтяной и горнотопливной литературы, $1958 .-75$ с.

54. Материалы по геологии и нефтегазоносности юга СССР / под ред. М.Д. Мирзоевой. - Л.: ГОСГЕОЛТЕХИЗДАТ, 1963. $252 \mathrm{c.}$

55. Понизовский А.М. Соляные ресурсы Крыма. Симферополь. Симферополь: Изд-во «Крым», 1965. - 83 с.

56. Доленко Г.Н., Парыляк А.И., Копач И.П. Структурно-тектонические этажи нефтегазоносности Крымской нефтегазоносной провинции // Республиканский межведомственный сборник. - Киев: Наукова думка, 1967. - С. 5-16.

57. Геология CCCP. Т. VIII. Крым. Ч. І. Геологическое описание / гл. ред. академик А.В. Сидоренко. - М.: Изд-во «Недра», 1969. $-582 \mathrm{c}$.

58. Геология СCCP. T. VIII. Крым. Полезные ископаемые / гл. ред. академик А.В. Сидоренко. - М.: Изд-во «Недра», 1974. - 210 с.
59. Чекунов А.В., Веселов А.А., Гилькман А.И. Геологическое строение и история развития Причерноморского прогиба. Киев: Наукова думка, 1976. - 164 с.

60. Инженерная геология СССР. В восьми томах. Кавказ, Крым, Карпаты / гл. ред. Е.М. Сергеев, Г.А. Голодковская. - М.: Изд-во Московского университета, 1978. - 360 с.

61. Казанцев Ю.В. Тектоника Крыма. - М.: Изд-во «Наука», 1982. $-112 \mathrm{c}$.

62. Структурная геология Крыма / Ю.В. Казанцев, Т.Т. Казанцева, М.Ю. Аржавитина, П.В. Аржавитин, Н.И. Бехер, А.А. Терехов, С.В. Попович. - Уфа: БНЦ Ур0 АН СССР, 1989. - 156 с.

63. Тихоненков Ю.Э. Индексация объектов гидрогеологической стратификации // Разведка и охрана недр. - 2006. - № 2. C. $47-50$.

64. Клюкин А.А. Экзогеодинамика Крыма. - Симферополь: Таврия, 2007. -320 c.

65. Юдин В.В. Геодинамика Крыма. - Симферополь: ДИАЙПИ, 2011. -335 c.

66. Новиков Д.А., Черных А.В., Дульцев Ф.Ф. Новая схема гидрогеологической стратификации города федерального значения Севастополь // Подземные воды Востока России: Материалы Всероссийского совещания по подземным водам Востока России (XXII Совещание по подземным водам Сибири и Дальнего Востока с международным участием). - Новосибирск: ИНГГ CO PAH, 2018. - C. 346-351.

67. Мартакова Е.Я., Попов В.Ф., Краснов Е.В. Отчет «0 поисковоразведочных работах на воду для целей водоснабжения г. Севастополя и Ю.Б. Крыма». - Днепропетровск: Севастопольская гидрогеологическая партия, Крымская комплексная геологическая экспедиция, трест Днепрогеология, Главгеология, 1959. $-166 \mathrm{c}$.

68. Новиков Д.А., Черных А.В., Дульцев Ф.Ф. Особенности гидрогеологии верхнеюрских отложений юго-западных районов Крымского полуострова // Ученые записки Крымского федерального университета имени В.И Вернадского. География. Геология. - 2018. - Т. 4 (70). - № 4. - С. 268-288.

69. Новиков Д.А., Черных А.В., Дульцев Ф.Ф. Особенности гидрогеологии верхнеюрских отложений юго-западных районов Крымского полуострова // Изучение и использование естественных и искусственных подземных пространств и закарстованных территорий: материалы Всероссийской научно-практической конференции. - Симферополь, 2018. - С. 105-109.

70. Geochemistry of natural waters of the Baydar valley (Crimean Peninsula) / L.A. Nichkova, D.A. Novikov, A.V. Chernykh, F.F. Dultsev, G.A. Sigora, T.Yu. Khomenko // E3S Web of Conferences. - 2019. - V. 98. - P. 01036.

71. Distribution of the stable isotopes $(\delta 180, \delta \mathrm{D}$ и $\delta 13 \mathrm{C})$ in natural waters of the Baydar valley (Crimean Peninsula) / D.A. Novikov, L.A. Nichkova, A.V. Chernykh, F.F. Dultsev, A.N. Pyryaev, G.A. Sigora, T.Yu. Khomenko // E3S Web of Conferences. 2019. - V. 98. - P. 01038-01038.

72. Novikov D.A., Chernykh A.V., Dultsev F.F. Groundwater quality assessment of Upper Jurassic sediments in the southwestern districts of the Crimean Peninsula for drinking and agricultural water supply // Ecology and Industry of Russia. - 2019. V. 23. - Iss. 4. - P. 52-57.

73. Гидрогеология и гидрогеохимия Крымского полуострова в свете проблемы питьевого водоснабжения / Д.А. Новиков, А.В. Черных, Ф.Ф. Дульцев, К.В. Сесь // Подземные воды Востока России: Материалы Всероссийского совещания по подземным водам Востока России (XXII Совещание по подземным водам Сибири и Дальнего Востока с международным участием). - Новосибирск: ИНГГ СО РАН, 2018. - С. 339-346.

Поступила 20.11.2018 г. 


\section{Информация об авторах}

Новиков Д.А., кандидат геолого-минералогических наук, заведующий лабораторией гидрогеологии осадочных бассейнов Сибири Института нефтегазовой геологии и геофизики им. А.А. Трофимука Сибирского отделения Российской академии наук; доцент кафедр геологии месторождений нефти и газа и общей и региональной геологии Новосибирского национального исследовательского государственного университета.

Черных A.B., младший научный сотрудник лаборатории гидрогеологии осадочных бассейнов Сибири Института нефтегазовой геологии и геофизики им. А.А. Трофимука Сибирского отделения Российской академии наук.

Дульщев Ф.Ф., младший научный сотрудник лаборатории гидрогеологии осадочных бассейнов Сибири Института нефтегазовой геологии и геофизики им. А.А. Трофимука Сибирского отделения Российской академии наук. 
UDC 556.382(477.75)

\title{
NEW LOOK AT HYDROGEOLOGICAL CONDITIONS OF THE FEDERAL CITY OF SEVASTOPOL
}

\section{Dmitry A. Novikov, ${ }^{1,2}$}

NovikovDA@ipgg.sbras.ru

\author{
Anatoliy V. Chernykh', \\ ChernykhAV@ipgg.sbras.ru
}

Fedor F. Dultsev',

DultsevFF@ipgg.sbras.ru

1 Trofimuk Institute of Petroleum Geology and Geophysics of Siberian Branch of Russian Academy of Sciences,

3, Koptyug avenue, Novosibirsk, 630090, Russia.

${ }^{2}$ Novosibirsk State University,

1, Pirogov street, Novosibirsk, 630090, Russia.

The relevance of the work consists in compilation of all available hydrogeological materials (published and fund) on the territory of the city of federal significance Sevastopol and drawing up in accordance with existing methodological recommendations the new generation scheme of hydrogeological stratification and a hydrogeological map for the first time in the last 50 years. The studied territory has a rich history from ancient times and as a consequence, year-round it is a favorite place in the tourist routes along the Crimean peninsula. The increasing flow of tourists and satisfaction of the current and future needs of the Sevastopol urban agglomeration in quality drinking water is one of the primary tasks of ensuring social stability, protecting health and increasing the life expectancy of the population (436 thousand people as of 01.01.2018). Currently, 9 water intakes (Orlovsky, Lyubimov, Rodnikovsky and others) are used in the city for the purposes of centralized household and drinking water supply. Most of them exploit the water-bearing complex of Miocene sediments. If one analyzes the situation with the underground water supply of the city of Sevastopol as a whole, it can be stated that the approved operational reserves at operating water intakes are at best 30-40\%, with the exception of Inkerman water intake, where this figure reaches 90-93\%. But the issue of underground water supply and development of existing water intakes is not simple. Errors in the operation of the Orlovsky water intake in the 1980s have already led to disastrous consequences for the change in chemical composition of groundwater in the exploited aquifer. In this regard, the issue of underground water supply must begin with the creation of a modern hydrogeological model, which first of all implies the actualization of the hydrogeological stratification scheme and the hydrogeological map of the city of Sevastopol.

The aim of the research is to reveal the features of the hydrogeological structure of the city of federal significance of Sevastopol on the basis of a detailed analysis of archival, published and field research, and to compile, in accordance with existing methodological recommendations, a new generation scheme of hydrogeological stratification and a hydrogeological map.

Methods. The methods of I.K. Zaitsev, B.N. Arkhangelsky, E.L. Baskov, M.S. Altovsk, A.S. Ryabchenkov, N.V. Rogovskaya, M.R. Nikitin, B.E. Antypko and others researchers, the latest methodological recommendations of the Ministry of Natural Resources of Russia and VSEGEI on the compilation of hydrogeological maps and schemes of hydrogeological stratification, fund and published data were used. Results. The hydrogeological data on the territory of the city of federal significance Sevastopol is summarized and a hydrogeological map and stratification scheme were compiled. The data on the main aquifers and horizons in the region are presented. A brief description of their chemical composition is given. Two water-bearing structural stage (Mesozoic and Cenozoic) are distinguished in the region of investigation. They include 7 aquifers: 1$)$ complex of Pliocene and Quaternary deposits $\left.-8\left(N_{2}-a Q\right) ; 2\right) ;$ Miocene $\left.-8\left(N_{1}\right) ; 3 ; 3\right)$ Paleocene-Eocene-8( $\left.P_{1}-P_{2}\right)$; 4) Upper Cretaceous - $8\left(K_{2}\right)$; 5) Lower Cretaceous - $8\left(K_{1}\right)$; 6) Upper Jurassic - 8 $\left(J_{3}\right)$; 7) the Upper Triassic-Middle Jurassic $-8\left(T_{3}-J_{2}\right)$. It is established that fractured-porous, fissured-karstic, fractured and pressure-fractured waters with total mineralization up to 1,5 g/d $\mathrm{dm}^{3}$ are common in the lower (Mesozoic) aquifers, whereas in the upper (Cenozoic) aquifers mineralization varies from $0,4-0,5$ to $10,3 \mathrm{~g} / \mathrm{dm}^{3}$ (up to $35 \mathrm{~g} / \mathrm{dm}^{3}$ in coastal areas). According to the chemical composition (within Shchukarev's classification) water composition is very diverse and there are 37 chemical types of water from fresh $\mathrm{Ca}-\mathrm{HCO}_{3}$ to saline $\mathrm{Na}-\mathrm{Cl}$. The composition is dominated by ground waters of hydrocarbonate, hydrocarbonate chloride and chloride calcium and calcium-sodium types with total mineralization ranging from 0,16 to $2,63 \mathrm{~g} / \mathrm{dm}^{3}$. Salinity of most groundwaters does not exceed $0,6 \mathrm{~g} / \mathrm{dm}^{3}$.

Key words:

Groundwater, hydrogeological map, hydrogeological stratification, Sevastopol city, Crimea.

The research was financially supported by the Russian Foundation for Basic Research and Sevastopol within the research project no.18-45-920032 p_a.

\section{REFERENCES}

1. Raftery A.E., Zimmer A., Frierson D.M.V., Startz R., Liu P. Less than $2{ }^{\circ} \mathrm{C}$ warming by 2100 unlikely. Nature Climate Change, 2017, vol. 7, pp. 637-641.

2. Parubets 0.V. Climate change in the Crimea. Scientific Notes of the Crimean Federal V.I.Vernadsky University. Geography. Geology, 2009, vol. 22 (61), no. 2, pp. 88-96. In Rus.
3. Abu Jabal M.S., Abustan I., Rozaimy M.R., El Najar H. Groundwater beneath the urban area of Khan Younis City, southern Gaza Strip (Palestine): assessment for multi-domestic purposes. Arabian Journal of Geosciences, 2017, vol. 10, pp. 257-272.

4. Aloni A., Brenner A. Use of Cotton as a Carbon Source for Denitrification in Biofilters for Groundwater Remediation. Water, 2017, vol. 9, pp. 714-725. 
5. Arora A.S. Urban stormwater - greywater management system for sustainable urban water management at sub-watershed level. E3S Web of Conferences 22, 2017. $7 \mathrm{p}$.

6. Asadi P., Ataie-Ashtiani B., Beheshti A. Vulnerability assessment of urban groundwater resources to nitrate: the case study of Mashhad, Iran. Environmental Earth Sciences, 2017, vol. 76, pp. 41-56.

7. Castiglioni S., Davoli E., Riva F., Palmiotto M., Camporini P., Manenti A., Zuccato E. Mass balance of emerging contaminants in the water cycle of a highly urbanized and industrialized area of Italy. Water Research, 2018, vol. 131, pp. 287-298.

8. Chakraborti D., Das B., Rahman M.M., Nayak B., Pal A., Sengupta M.K., Ahamed S., Hossain Md.A., Chowdhury U.K., Kumar Biswas B., Saha K.C., Dutta R.N. Arsenic in groundwater of the Kolkata Municipal Corporation (KMC), India: Critical review and modes of mitigation. Chemosphere, 2017, vol. 180, pp. 437-447.

9. Chitsazan M., Aghazadeh N., Mirzaee Y., Golestan Y. Hydrochemical characteristics and the impact of anthropogenic activity on groundwater quality in suburban area of Urmia city, Iran. Environment, Development and Sustainability, 2017, vol. 21, no. 1, pp. 1-21.

10. Fallahzadeh R.A., Ghaneian M.T., Miri M., Dashti M.M. Spatial analysis and health risk assessment of heavy metals concentration in drinking water resources. Environmental Science and Pollution Research, 2017, vol. 24, pp. 24790-24802.

11. Guo X., Zuo R., Shan D., Cao Y., Wang J., Teng Y., Fu Q., Zheng B. Source apportionment of pollution in groundwater source area using factor analysis and positive matrix factorization methods. Human and Ecological Risk Assessment: An Inter national Journal, 2017, vol. 23, no. 6, pp. 1417-1436.

12. Jangam C., Pujari P. Impact of on-site sanitation systems on groundwater sources in a coastal aquifer in Chennai, India. Environmental Science and Pollution Research, 2017, vol. 26, no. 3, pp. 1-10.

13. Kessasra F., Mesbah M., Khemissa Z., Bouab N., KhaledKhodja S., Lamari H. Combined hydrogeological and nitrate modelling to manage water resources of the Middle Soummam Aquifer, Northeast of Algeria. Arabian Journal of Geosciences, 2017, vol. 10 , pp. 368-388.

14. Lasagna M., De Luca D.A. Evaluation of sources and fate of nitrates in the western Po plain groundwater (Italy) using nitrogen and boron isotopes. Environmental Science and Pollution Research, 2017, vol. 26, no. 3, pp. 1-16.

15. Lins-de-Barros F.M. Integrated coastal vulnerability assessment: A methodology for coastal cities management integrating socioeconomic, physical and environmental dimensions - Case study of Regia o dos Lagos, Rio de Janeiro, Brazil. Ocean \& Coastal Ma nagement, 2017, vol. 149, pp. 1-11.

16. Liu J., Jiang L.H., Zhang C.J., Li P., Zhao T.K. Nitrate-nitrogen contamination in groundwater: Spatiotemporal variation and driving factors under cropland in Shandong Province, China. IOP Conf. Series: Earth and Environmental Science, 2017, vol. 82, 012059 .

17. Malakar A., Islam S., Ali Md.A., Ray S. Rapid decadal evolution in the groundwater arsenic content of Kolkata, India and its correlation with the practices of her dwellers. Environmental Monitoring and Assessment, 2016, vol. 188, pp. 584-595.

18. Mali N., Cerar S., Koroša A., Auersperger P. Passive sampling as a tool for identifying micro - organic compounds in groundwater. Science of the Total Environment, 2017, vol. 593-594, pp. 722-734.

19. Margenat A., Matamoros vol., Díez S., Cañameras N., Comas J., Bayona J.M. Occurrence of chemical contaminants in peri-urban agricultural irrigation waters and assessment of their phytotoxicity and crop productivity. Science of the Total Environment, 2017, vol. 599-600, pp. 1140-1148.
20. Merghem K.A., Jilali A., Alnedhary A.A., Halouani H.E., Dssouli K. Impact of wastewater on groundwater resources in Sana'a basin, Yemen. Arabian Journal of Geosciences, 2016, vol. 9, no. 268, pp. 1-14.

21. Pandith M., Kaplay R.D, Potdar S.S., Sangnor H., Rao A.D. Impact of urbanization coupled with drought situations on groundwater quality in shallow (basalt) and deeper (granite) aquifers with special reference to fluoride in Nanded - Waghala $\mathrm{Mu}$ nicipal Corporation, Nanded District, Maharashtra (India). Environmental Monitoring and Assessment, 2017, vol. 189, pp. 428-442.

22. Santucci L., Carol E., Borzi G., García M.G. Hydrogeochemical and isotopic signature of surface and groundwater in a highly industrialized sector of the Rio de la Plata coastal plain (Argentina). Marine Pollution Bulletin, 2017, vol. 120, pp. 387-395.

23. Selvakumar S., Chandrasekar N., Kumar G. Hydrogeochemical characteristics and groundwater contamination in the rapid urban development areas of Coimbatore, India. Water Resources and Industry, 2017, vol. 17, pp. 26-33.

24. Selvam S., Venkatramanan S., Sivasubramanian P., Chung S.Y., Singaraja C. Geochemical Characteristics and Evaluation of Minor and Trace Elements Pollution in Groundwater of Tuticorin City, Tamil Nadu, India using Geospatial Techniques. Journal Geological Society of India, 2017, vol. 90, pp. 62-68.

25. Silva M.M.V.G., Gomes E.M.C., Isaías M., Azevedo J.M.M., Zeferino B. Spatial and seasonal variations of surface and groundwater quality in a fast-growing city: Lubango, Angola. Environmental Earth Sciences, 2017, no. 76, pp. 790-807.

26. Su H., Kang W., Xu Y., Wang J. Evaluation of groundwater quality and health risks from contamination in the north edge of the Loess Plateau, Yulin City, Northwest China. Environmental Earth Sciences, 2017, vol. 76, pp. 467-488.

27. Teatini P., Isotton G., Nardean S., Ferronato M., Mazzia A., Da Lio C., Zaggia L., Bellafiore D., Zecchin M., Baradello L., Cellone F., Corami F., Gambaro A., Libralato G., Morabito E., Ghirardini A.V., Broglia R., Zaghi S., Tosi L. Hydrogeological effects of dredging navigable canals through lagoon shallows. A case study in Venice. Hydrology and Earth System Sciences, 2017, vol. 21, pp. 5627-5646.

28. Weaver J.W., Murray A.R., Kremer F.V. Estimation of the proximity of private domestic wells to underground storage tanks: Oklahoma pilot study. Science of the Total Environment, 2017, vol. 609 , pp. $1589-1599$.

29. White D., Lapworth D.J., Stuart M.E., Williams P.J. Hydrochemical profiles in urban groundwater systems: New insights into contaminant sources and pathways in the subsurface from legacy and emerging contaminants. Science of the Total Environment, 2016, vol. 562, pp. 962-973.

30. Wilson D.C. Potential urban runoff impacts and contaminant distributions in shoreline and reservoir environments of Lake Havasu, southwestern United States. Science of the Total Environment, 2018, vol. 621, pp. 95-107.

31. Wyman D.A., Koretsky C.M. Effects of road salt deicers on an urban groundwater - fed kettle lake. Applied Geochemistry, 2018, vol. 89, pp. 265-272.

32. Zhang Y., Ye S., Wu J., Stahl Jr. R.G. Assessing Risks at a Former Chemical Facility, Nanjing City, China: An Early Test of the New Remediation Guidelines for Waste Sites in China. Water, 2017, vol. 9, pp. 657-672.

33. Metodicheskoe pismo po podgotovke skhem gidrogeologicheskoy stratifikatsii [Methodical letter on the preparation of schemes of hydrogeological stratification]. Moscow, Ministry of Natural Resources of the Russian Federation, 1999. 10 p.

34. Metodicheskie rekomendatsii po sostavleniyu kart gidrogeologicheskogo rayonirovaniya masshtaba 1:2500000, skhem gidrogeologicheskoy stratifikatsii i klassifikatorov obyektov gidrogeolo- 
gicheskogo rayonirovaniya i stratifikatsii [Methodological recommendations for compiling maps of hydrogeological zoning at a scale of 1: 2,500,000, schemes of hydrogeological stratification and classifiers of objects of hydrogeological zoning and stratification]. Moscow, Ministry of Natural Resources of the Russian Federation, 2004. $29 \mathrm{p}$.

35. Metodicheskoe rukovodstvo po sostavleniyu i podgotovke k izdaniyu listov Gosudarstvennoy geologicheskoy karty Rossiyskoy Federatsii masshtaba 1:200000 (vtorogo izdaniya). Versiya 1.2 . [Methodological guidelines for compiling and preparing for publication of sheets of the State Geological Map of the Russian Federation 1: 200000 scale (second edition). Version 1.2.]. St. Petersburg, VSEGEI Cartographic Factory, 2015. 163 p.

36. Metodicheskoe rukovodstvo po sostavleniyu i podgotovke $k$ izdaniyu listov Gosudarstvennoy geologicheskoy karty Rossiyskoy Federatsii masshtaba 1:200000 (vtoroye izdaniye). Versiya 1.3. [Methodological guidelines for compiling and preparing for publication of the State Geological Map of the Russian Federation at a scale of 1: 200000 (second edition). Version 1.3.]. St. Petersburg, VSEGEI Cartographic Factory, 2017. $173 \mathrm{p}$.

37. Gidrogeologiya SSSR. T. VIII. Krym [Hydrogeology of the USSR. Vol. VIII. Crimea]. Ed. by A.V. Sidorenko. Moscow, Nedra Publ., 1970. $364 \mathrm{p}$.

38. Gidrogeologiya SSSR. T. VIII. Krym [Hydrogeology of the USSR. Vol. VIII. Crimea]. Ed. by A.V. Sidorenko. Moscow, Nedra Publ., $1971.55 \mathrm{p}$.

39. Karta podzemnykh vod: L-(36), (37). Gosudarstvennaya geologicheskaya karta SSSR (Simferopol). Karta podzemnykh vod, masshtab: 1:1000000 [Map of groundwater: L-(36), (37). State Geological Map of the USSR (Simferopol). Map of groundwater, scale: 1:1000000]. Ed. by I.N. Pavlovets. St-Petersburg, VSEGEI Publ., 1983. 1 p.

40. Geologicheskaya karta: L-36-XXXIV, XXXV. Geologicheskaya karta SSSR. Seriya Krymskaya, masshtab: 1:200000, seriya: Krymskaya [Geological map: L-36-XXXIV, XXXV. Geological map of the USSR. Crimean series, scale 1:200000, Serie: Crimean]. Ed. by M.V. Muratov. Dnepropetrovsk, S. Ordzhonikidze MGRI, trust Dneprogeology Publ., $1965.1 \mathrm{p}$.

41. Geologicheskaya karta: L-37-XIX, XXV. Gosudarstvennaya geologicheskaya karta SSSR. Seriya Krymskaya, masshtab: 1:200000, seriya: Krymskaya [Geological map: L-37-XIX, XXV. State geological map of the USSR. Crimean series, scale 1:200000, series: Crimean]. Ed. by M.V. Muratov. Dnepropetrovsk, Trest Dneprogeologiya, trest Krymneftegazrazvedka Publ., 1971. 1 p.

42. Geologicheskaya karta: L-36-XXIX. Geologicheskaya karta SSSR Seriya Krymskaya, masshtab: 1:200000, seriya: Krymskaya [Geological map: L-36-XXIX. Geological map of the USSR. Crimean series, scale 1:200000, series: Crimean]. Ed. by M.A. Kalatsuk. Kiev, CCL Trust Kievgeologiya Publ., 1973. 1 p.

43. Geologicheskaya karta: Geologicheskaya karta Gornogo Kryma, masshtab: 1:20000 [Geological map: Geological map of the Mountainous Crimea, scale 1:20000]. Ed. by N.E. Derenyuk. Moscow, Mingeo USSR Publ., 1984. 1 p.

44. Geologicheskaya karta: L-(36), (37). Gosudarstvennaya geologicheskaya karta SSSR (Simferopol), masshtab: 1:1000000 [Geological map: L-(36), (37). State Geological Map of the USSR (Simferopol), scale 1:1000000]. Eds. D.F. Volodin, P.N. Storchak. Kiev, Central thematic expedition of the Ministry of Geology of the Ukrainian SSR Publ., 1986. 1 p.

45. Geologicheskaya karta: Geologicheskaya karta Gornogo i Predgor nogo Kryma, masshtab: 1:200000 [Geological map: Geological map of the Mountainous and Foothill Crimea, scale 1:200000]. Ed. by V.V. Yudin. Simferopol, Research and Production Center of Soyuzkart Publ., 2009. 1 p.

46. Karta domelovykh otlozheniy: L-(36), (37). Gosudarstvennaya geologicheskaya karta SSSR (Simferopol). Karta domelovykh obrazovaniy, masshtab: 1:1000000 [Map of the pre-Cretaceous de- posits: L-(36), (37). State Geological Map of the USSR (Simferopol). Map of pre-Cretaceous formations, scale 1:1000000]. Ed. by P.N. Storchak. St-Petersburg, FGBU VSEGEI Publ., 1983. 1 p.

47. Karta dochetvertichnykh obrazovaniy: L-(36), (37). Gosudarstvennaya geologicheskaya karta SSSR (Simferopol). Karta dochetvertichnykh obrazovaniy, masshtab: 1:1000000 [Map of pre-Quaternary formations: L-(36), (37). State Geological Map of the USSR (Simferopol). Map of pre-Quaternary formations, scale 1:1000000]. Ed. by P.N. Storchak. St-Petersburg, FGBU VSEGEI Publ., 1983. $1 \mathrm{p}$.

48. Karta poleznykh iskopayemykh: L-37-XIX, XXV. Karta poleznykh iskopayemykh SSSR. Seriya Krymskaya, masshtab: 1:200000, seriya: Krymskaya [Mineral Map: L-37-XIX, XXV. Map of minerals of the USSR. Crimean series, scale 1:200000, Serie: Crimean]. Ed. by M.V. Muratov. Dnepropetrovsk, Trust Dneprogeology, trust Krimneftegazrazvedka Publ., 1971. 1 p.

49. Karta poleznykh iskopayemykh: L-(36), (37). Gosudarstvennaya geologicheskaya karta SSSR (Simferopol). Karta poleznykh iskopayemykh, masshtab: 1:1000000 [Mineral Map: L- (36), (37). State Geological Map of the USSR (Simferopol). Map of minerals, scale 1:1000000]. Ed. by P.N. Storchak. St-Petersburg, FSBB VSEGEI Publ., $1983.1 \mathrm{p}$.

50. Karta chetvertichnykh otlozheniy: L-(36), (37). Gosudarstvennaya geologicheskaya karta SSSR (Simferopol). Karta chetvertichnykh otlozheniy, masshtab: 1:1000000 [Map of Quaternary deposits: L- (36), (37). State Geological Map of the USSR (Simferopol). Map of Quaternary deposits, scale 1:1000000]. Ed. by P.N. Storchak. St-Petersburg, FGBU VSEGEI Publ., 1983. 1 p.

51. Shvartsev S.L. Obshaya gidrigeologiya [General hydrogeology]. Moscow, Nedra Publ., 1996. 423 p.

52. Geologicheskaya karta Ukrainy: Krymskaya seria: L-36-XXVIII, L-36-XXXIV, masshtab: 1:200000 [Geological map of Ukraine: series: Crimean: L-36-XXVIII, L-36-XXXIV, scale 1:2000000]. Ed. by S.V. Biletskiy. Kiev, SGSFP Yushnogeocentr Publ., 2006. 1 p.

53. Dikenshteyn G.Kh., Beznosov N.V., Golubnichaya L.M., Zagoruyko V.A., Kamenetskiy A.E., Moksyakova A.M., Oslopovskiy A.P., Snegireva 0.V., Khelkvist V.G., Shutskaya E.K. Geologiya i neftegazonosnost stepnogo i predgornogo Kryma [Geology and oil and gas content of the steppe and foothill Crimea]. Moscow, State Scientific and Technical Publishing House of Oil and Mining and Fuel Literature, 1958. 75 p.

54. Materialy po geologii i neftegazonosnosti yuga SSSR [Materials on geology and oil and gas potential of the south of the USSR]. Ed. by M.D. Mirzoeva. Leningrad, Gosgeoltekhizdat Publ., 1963. $252 \mathrm{p}$.

55. Ponizovskiy A.M. Solyanye resursy Kryma. Simferopol [The salt resources of the Crimea. Simferopol]. Simferopol, Crimea Publ. house, $1965.83 \mathrm{p}$.

56. Dolenko G.N., Parylyak A.I., Kopach I.P. Strukturno-tektonicheskiye etazhi neftegazonosnosti Krymskoy neftegazonosnoy provintsii [Structural-tectonic floors of oil and gas content of the Crimean oil and gas province]. Kiev, Naukova Dumka Publ., 1967. P. 5-16.

57. Geologiya SSSR. T. VIII. Krym. Ch. I Geologicheskoye opisanie [Geology of the USSR. Vol. VIII. Crimea. P. I Geological Description]. Ed. by A.V. Sidorenko. Moscow, Nedra Publ., 1969. 582 p.

58. Geologiya SSSR. T.VIII.Krym. Poleznye iskopayemye [Geology of the USSR. Vol. VIII. Crimea. Minerals]. Ed. by A.V. Sidorenko. Moscow, Nedra Publ., 1974. 210 p.

59. Chekunov A.V., Veselov A.A., Gilkman A.I. Geologicheskoe stroyenie $i$ istoriya razvitiya Prichernomorskogo progiba [Geological structure and history of development of the Black Sea trough]. Kiev, Naukova Dumka Publ., 1976. 164 p.

60. Sergeev E.M., Golodkovskaya G.A. Inzhenernaya geologiya SSSR. Kavkaz, Krym, Karpaty [Engineering geology of the USSR. Caucasus, Crimea, Carpathians]. Moscow, Publ. house of Moscow University, 1978. 360 p. 
61. Kazantsev Yu.V. Tektonika Kryma [Tectonics of the Crimea]. Moscow, Nauka Publ., 1982. 112 p.

62. Kazantsev Yu.V., Kazantseva T.T., Arzhavitina M.Yu., Arzhavitin P.V., Bekher N.I., Terekhov A.A., Popovich S.V. Strukturnaya geologiya Kryma [Structural geology of the Crimea]. Ufa, BNC Ur0 AN SSSR Publ., 1989. 156 p.

63. Tikhonenkov Yu.E. Indexing of Hydrogeological Stratification Objects. Prospect and protection of mineral resources, 2006, no. 2, pp. 47-50. In Rus.

64. Klyukin A.A. Ekzogeodinamika Kryma [Exogeodynamics of the Crimea]. Simferopol, Tavria Publ., 2007. 320 p.

65. Yudin V.V. Geodinamika Kryma [Geodynamics of the Crimea]. Simferopol, DIAYPI Publ., 2011. 35 p.

66. Novikov D.A., Chernykh A.V., Dultsev F.F. Novaya skhema gidrogeologicheskoy stratifikatsii goroda federalnogo znacheniya Sevastopol [New scheme of hydrogeological stratification of the city of federal significance Sevastopol]. Podzemnye vody Vostoka Rossii. Materialy Vserossiyskogo soveshchaniya po podzemnym vodam Vostoka Rossii (XXII Soveshchaniye po podzemnym vodam Sibiri i Dalnego Vostoka s mezhdunarodnym uchastiyem) [Underground waters of the East of Russia. Materials of the AllRussian meeting on the underground waters of the East of Russia (XXII Meeting on underground waters of Siberia and the Far East with international participation)]. Novosibirsk, IPGG SB RAS, 2018. pp. 346-351.

67. Martakova E.Ya., Popov V.F., Krasnov E.V. Otchet «0 poiskovorazvedochnykh rabotakh na vodu dlya tseley vodosnabzheniya g. Sevastopolya i Yu.B. Kryma» [The report «On exploration for water for the purposes of water supply in Sevastopol and S.C. Crimea»]. Dnepropetrovsk, Sevastopolskaya gidrogeologicheskaya partiya, Krymskaya kompleksnaya geologicheskaya ekspeditsiya, trest Dneprogeologiya, Glavgeologiya Publ., 1959. 166 p.

68. Novikov D.A., Chernykh A.V., Dultsev F.F. Features of hydrogeology of the Upper Jurassic deposits of the southwestern regions of the Crimean peninsula. Scientific notes of the Crimean Federal University named after V.I.Vernadsky. Geography.Geology, 2018, vol. 4 (70), no. 4, pp. 268-288. In Rus.
69. Novikov D.A., Chernykh A.V., Dultsev F.F. Osobennosti gidrogeologii verkhneyurskikh otlozheniy yugo-zapadnykh rayonov Krymskogo poluostrova [Features of hydrogeology of the Upper Jurassic deposits of the southwestern regions of the Crimean peninsula]. Izucheniye $i$ ispolzovanie estestvennykh $i$ iskusstvennykh podzemnykh prostranstv i zakarstovannykh territoriy. Materialy Vserossiyskoy nauchno-prakticheskoy konferentsii [Study and use of natural and artificial underground spaces and karst territories. Materials of the All-Russian Scientific and Practical Conference]. Simferopol, 2018. pp. 105-109.

70. Nichkova L.A., Novikov D.A., Chernykh A.V., Dultsev F.F., Sigora G.A., Khomenko T.Yu. Geochemistry of natural waters of the Baydar valley (Crimean Peninsula). E3S Web of Conferences, 2019, vol. 98 , pp. 01036.

71. Novikov D.A., Nichkova L.A., Chernykh A.V., Dultsev F.F., Pyryaev A.N., Sigora G.A., Khomenko T.Yu. Distribution of the stable isotopes ( $\delta 180, \delta \mathrm{D}$ и $\delta 13 \mathrm{C})$ in natural waters of the Baydar valley (Crimean Peninsula). E3S Web of Conferences, 2019, vol. 98 , pp. 01038.

72. Novikov D.A., Chernykh A.V., Dultsev F.F. Groundwater quality assessment of Upper Jurassic sediments in the southwestern districts of the Crimean Peninsula for drinking and agricultural water supply. Ecology and Industry of Russia, 2019, vol. 23, Iss. 4 , pp. 52-57.

73. Novikov D.A., Chernykh A.V., Dultsev F.F., Ses K.V. Gidrogeologiya i gidrogeokhimiya Krymskogo poluostrova v svete problemy pityevogo vodosnabzheniya [Hydrogeology and hydrogeochemistry of the Crimean peninsula in the light of the problem of drinking water supply]. Podzemnye vody Vostoka Rossii: Materialy Vserossiyskogo soveshchaniya po podzemnym vodam Vostoka Rossii (XXII Soveshchanie po podzemnym vodam Sibiri i Dalnego Vostoka s mezhdunarodnym uchastiyem) [Underground waters of the East of Russia: Materials of the All-Russian meeting on the underground waters of the East of Russia (XXII Meeting on underground waters of Siberia and the Far East with international participation)]. Novosibirsk, IPGG SB RAS, 2018. pp. 339-346.

Received: 20 November 2018.

\section{Information about the authors}

Dmitry A. Novikov, Cand. Sc., head of the laboratory of sedimentary basins hydrogeology of Siberia, Trofimuk Institute of Petroleum Geology and Geophysics of Siberian Branch of Russian Academy of Sciences; associate professor, Novosibirsk State University.

Anatoliy V. Chernykh, junior researcher, Trofimuk Institute of Petroleum Geology and Geophysics of Siberian Branch of Russian Academy of Sciences.

Fedor F. Dultsev, junior researcher, Trofimuk Institute of Petroleum Geology and Geophysics of Siberian Branch of Russian Academy of Sciences. 